\title{
THE COINTEGRATION RELATIONSHIP BETWEEN BITCOIN PRICES AND MAJOR WORLD STOCK INDICES: AN ANALYSIS WITH ARDL MODEL APPROACH
}

\author{
DOI: 10.17261/Pressacademia.2017.748 \\ JEFA-V.4-ISS.4-2017(3)-p.377-392
}

\author{
Cuneyt Dirican ${ }^{1}$, Ismail Canoz ${ }^{2}$ \\ ${ }^{1}$ Istanbul Arel University, School of Applied Sciences, Tepekent, Büyükçekmece, Istanbul, Turkey. cuneytdirican@arel.edu.tr \\ ${ }^{2}$ Istanbul Arel University, School of Applied Sciences, Tepekent, Büyükçekmece, Istanbul, Turkey. ismailcanoz@arel.edu.tr
}

To cite this document

Dirican, C. and Canoz, I. (2017). The cointegration relationship between Bitcoin prices and major world stock indices: an analysis with ARDL model approach. Journal of Economics, Finance and Accounting (JEFA), V.4, Iss.4, p377-392.

Permanent link to this document: http://doi.org/10.17261/Pressacademia.2017.748

Copyright: Published by PressAcademia and limited licenced re-use rights only.

\begin{abstract}
Purpose - Aiming to discover whether Bitcoin prices have an effect on investor decisions in stock market transactions sounds exciting. Therefore, among investment, money, payment system functionalities of the cryptocurrencies which are very popular on economic and financial agenda nowadays, only the investment function regarding to the market volume of Bitcoin (which is very popular) is taken into consideration in this study.

Methodology - In the scope of the study, because similar analyses between cryptocurrencies and stock market indices do not exist in the literature, cointegration relation between them are examined. Thus, the cointegration between Bitcoin (since there are many cryptocurrencies and Bitcoin is very popular and has the highest proportion in all terms in general) and selected stock indices can be investigated by the ARDL boundary test method. Since the analysis method gives meaningful information in terms of different time periods, the price and index data of these variables have been analysed.

Findings- Cointegration relationship between Bitcoin prices and leading US and Chinese stock market indices is observed. Within this context, it can be told that investors in these stock markets could be influenced by Bitcoin prices in their long-term investment decision process. Any relationship was not found with BIST100, FTSE100 and NIKKEI225 indices.

Conclusion - Necessity to examine the relation among Bitcoin, cryptocurrencies and other investment instruments with payment systems, money, e-commerce figures and macroeconomic indicators in the light of the arguments and the results found in our analysis would add more value to the literature. In addition, other dimensions of this topic should be regulated and be analysed by new studies within the scope of other technological developments in the $4^{\text {th }}$ Industrial Revolution. It is also decided to analyse relationship among related Istanbul Stock Exchange sub-indices, the Turkish Lira, gold, money supply and other cryptocurrencies in the following/future studies.
\end{abstract}

Keywords: Bitcoin, cryptocurrency, stock exchange, capital markets, financial services, investment.

JEL Codes: O16, G11, G23

\section{BITCOIN FIYATLARI ILE DÜNYADAKI BAŞLICA BORSA ENDEKSLERI ARASINDAKI EŞBÜTÜNLEŞME ILIŞKISI: ARDL MODELI YAKLAŞIMI ILE ANALIZ}

\section{ÖZET}

Amaç - Bu çalışmada ekonomik ve finansal gündemde yoğun bir yer tutan kripto paralardan popüler olan Bitcoin'in yatırım, para, ödeme sistemi fonksiyonlarından salt yatırıma odaklanılmış ve yatırımcı kararlarında bir etkisi olup olmadığının ortaya çıkarılması hedeflenmiştir.

Yöntem - Çalışma kapsamında literatürde yapılan taramada kripto paralar ile hisse senedi piyasaları/endeskleri arasında salt ilişkiye yönelik bir analize rastlanmamıştır. ARDL sınır testi yöntemi ile Bitcoin (Çok fazla kripto para olması ve Bitcoin'in her açıdan en önde gelen olması nedeniyle) ve seçilmiş endeksler arasında bir eşbütünleşme aranması bu nedenle düşünülmüştür. Analiz yönteminin kısa ve uzun dönemde anlamlı sonuçlar vermesi nedeni ile bu değişkenlerin fiyat ve endeks verileri ARDL'de çalışılmıştır.

Bulgular - Bitcoin fiyatları ile önde gelen ABD ve Çin Borsa endeksleri arasında eşbütünleşme ilişkisi görülmüştür. Bu ilişki kapsamında Bitcoin fiyatlarının bu borsalardaki yatırımcıların uzun dönemdeki yatırım kararlarını etkileyebildiği sonucuna varılmıştır. Londra FTSE100 ve Tokyo NIKKEI 225 hisse senedi endekslerinde ve İstanbul BiST100 ile bir ilişki görülmemiştir.

Sonuç- Analiz sonuçlarımız ışığında Bitcoin, kripto paralar ile diğer yatırım araçları, ödeme sistemleri, para, e-ticaret verileri ve makro ekonomik göstergeler arasında bir ilişki olup olmadığını incelemek gereklidir. Buna ek olarak, bu konunun diğer boyutları, 4. Sanayi Devrimi'ndeki diğer teknolojik gelişmeler çerçevesinde yeni çalışmalar ile düzenlemelidir. Ayrıca, ilgili Borsa İstanbul alt endeksleri ile Türk Lirası, Bitcoin, altın, para arzı ve diğer kripto para birimleri arasındaki ilişkinin gelecek çalışmalar ile analiz edilmesine karar verilmiştir.

Anahtar Kelimeler: Bitcoin, kripto para, borsa, sermaye piyasası, finansal hizmetler, yatırım JEL Kodları: 016, G11, G23 


\section{GiRiş}

Finansal hizmetler insanoğlu için trampa ekonomisinden bu yana son derece önemli bir konudur. İnsanlığın gelişimi ile beraber intiyaçlar çeşitlendikçe ve teknoloji ilerledikçe döneminin imkânlarına göre farklı şekillerde işlem görmüştür. Günümüze yaklaştıkça merkez bankacılığı, klasik bankacılık, sigortacılık ve borsacılık anlayışı gelişmeye başlamış, iktisattaki farklı ekoller kapsamında para teorileri de gelişim göstermiştir. Faiz, merkez bankacılığı, kredi kanalı ve sıkışması, likidite tercihi ve tuzağı, analitik bilanço, açık piyasa işlemleri, piyasa riski, aktif pasif yönetimi gibi kavramlar literatürde sıkça tartışılmıştır. Finansal yönetim, işletme sermayesi, EBITDA, nakit akış tablosu gibi firmalara dair yeni kavramlar oluşmuştur. 2000'li yıllara doğru internetin gelişimi ile beraber "ikilik sayı düzeninde (internette) bankacılık" gündemdeki yerini almaya başlamıştır. Günümüzde ise akıllı mobil cihazların gelişimi, web teknolojileri ile beraber internet bankacılığının çok daha ötesinde, finansal hizmetler kavramının alt başlıklarına dair yenilikler hayatımıza girmiştir. Sosyal medyada Facebook bankacılı̆̆ı, mobil para transferi gibi kavramlar artık eskimeye başlarken elektronik para, yeni şifreleme teknolojileri ile türevlerinin yerini almaya başlamıştır. İşte son yıllardaki bu süreç içerisinde kripto para, blok zincirleri, Bitcoin gibi kavramlar finansal hizmetlerin yanında girişimcilerin, KOBI'lerin kreditör kurumlardan temin etmekte zorlandıkları fon ihtiyacını gidermek amacı ile daha çok kullanılmaya başlamış ve her geçen gün yatırımcılar tarafından daha çok tercih edilmişlerdir. Bu teknolojinin bankacılık sektörü dışında sermaye piyasasına da doğrudan etkisi bulunmaktadır. Henüz sigortacılık alanında kullanımı yaygın olmamakla beraber blok zincirleri boyutundan kısa vadede sanal kripto poliçeleşmesi ve teminat olarak görülmesi de söz konusu olabilecektir.

Bu çalışmada kripto para çeşitleri arasında en çok işlem gören Bitcoin bağımlı değişken olarak kabul edilmiştir. Kripto paraların çokluğu ve finansal hizmetlerdeki alt başlıkların derinliği nedeni ile çalışmada sadece Bitcoin kullanılmış ve yatırım aracı olma özelliği boyutuna indirgenerek analiz gerçekleştirilmiştir. Bu şekilde Bitcoin'in yatırım ve sermaye piyasası boyutundan hareketle önde gelen borsa endeksleri ile ilişkisi incelenmiş ve bazı borsa endeksleri ile olan eşbütünleşmesi anlamlı görüldüğünden gelecekte yatırımcıları ve finansal hizmetler sektörünü etkileyecek bulgular tartışılmıştır. Çalışmada eşbütünleşme ilişkisini kısa ve uzun dönemde sağlıklı olarak analiz etmeye imkân veren ARDL sınır testi kullanılmıştır. Durağanlık analizi sonrasında yapısal kırılganlık kontrolü yapıldıktan sonra modelin sağlıklı olduğuna karar verilerek analiz gerçekleştirilmiştir. Para ve finansal hizmetlere dair diğer alt başlıklar ve enflasyon, GSYiH gibi iktisadi kavramlar arasındaki eşbütünleşme, korelasyon, nedensellik ilişkileri çalışmanın boyutunu büyüteceği için daha sonraki akademik çalışmalarda değerlendirilmek üzere kapsam dışında bırakılmıştır. Borsa endeksleri ve Bitcoin arasında salt bir analize neredeyse hiç rastlanmadığından bu çalışmanın akademik ve profesyonel dünyaya katkı sunmak amacıyla yapılması kararlaştırılmıştır.

Web teknolojilerinin ve Sanayi 4.0 kapsamındaki diğer teknolojik gelişmelerin ilerleyen zamanlarda finansal hizmetler sektöründe, finans, muhasebe, iktisat, yönetim gibi sosyal bilimler başlıklarında birçok yeniliği tetikleyeceği, okullar ve doktrinler geliştireceği, mevcutları çürüteceği, kitapların ve çalışmaların güncellenmesine veya yenilenmesine yol açacağını, akademik dünyaya ve bilime bu vesile ile yeni katkılar sunacağını hipotez olarak öne sürmek gelinen nokta itibarı ile artık ütopik bir durum olmayacaktır (rmegold.com, ET:2017). Kripto paraların, blok zincirlerinin bu etkileşimlerine de ayrıca bakılması gereklidir (Bovaird, coindesk.com, ET:2017). Çalışmamııın bu yöndeki analizlere de yol göstereceği düşünülmektedir. Çalışmada kullanılan ARDL analiziyle, bazı borsa endeksleri ile Bitcoin arasındaki ilişkinin analizi ve bazıları arasında eşbütünleşme bulunması hem akademik hem profesyonel anlamda her iki tarafa da katkı sağlayacaktır.

Bu çalışmanın bulgular ve tartışmalar bölümünde listelendiği gibi ileride yapılacak ampirik, ekonometrik, kuramsal çalışmalara önemli bir kaynak olması hedeflenmektedir. Öte yandan bu çalışmanın sadece akademik olarak değil, aynı zamanda yatırımcı davranışları açısından da dikkate alınacak bir boyutu olduğu düşünülmektedir. Sonraki çalışmada para arzı, altın ve Bitcoin arasındaki ilişkilerin incelenmesi amaçlanmaktadır.

\subsection{Kripto Para Kavramları}

Kripto paralara ve Bitcoin'e yönelik tanımlara geçmeden önce elektronik parayı ve kavramlarını kısaca hatırlamak gerekecektir. İkilik sayı düzeninde çalışan iş̧lemciler (bilgisayarlar) ile akıllı cihazlarda saklanan, işlem gören her türlü sayısal değer, işleme taraf olanlar arasında bir işlem birimi ve değişim aracı olarak kabul gördüğünde bunu elektronik para olarak kabul etmek mümkün olacaktır. Elektronik paranın ihraççısı, banknot ve bozuk paralarda olduğu gibi merkez bankaları olabileceği gibi mevzuatın izin verdiği ölçüde bankalar, posta işletmeleri, telefon operatörleri ve gerekli kriterleri sağlayan herhangi bir tüzel kişilik işletme de olabilir. Kripto paraları bu durumdan ayıran en temel özellik ise buradadır. Kripto para ihraççısı her zaman bir tüzel kişilik veya merkez bankası olmak zorunda değildir, takası ve ödeme yöntemleri merkezi bir takas odasından bağımsız yapılabilmektedir. Daha da önemlisi günümüzde bir yasal mevzuatı olmayan, bağımsız ve tarafsız, sistemde herkes tarafından izlenebilen ve teyit edilen bir elektronik para cinsi olmasıdır (Üzer, 2017:12-14). Üzer, yine TCMB yeterlilik tezinde sanal para birimlerini incelemiş, kategorize etmiş ve tanımlamıştır. Buna göre sıralamada dijital parayı sanal para birimleri takip etmekte, sonrasında ise çevrilebilen (konvertibl) ve merkezi olmayan (ihraççısı ve otoritesi tek olmayan) paralar, son olarak ise şifreleme yöntemi nedeni ile kripto paralar gelmektedir. Avrupa Merkez Bankası'nın ilgili ilk (2012) ve revize raporunda (2015) sanal paraların şu şekilde tanımlandığını belirtmiştir: 
"Genellikle geliştiricileri tarafından ihraç ve kontrol edilen, belli bir sanal ortamın üyeleri tarafından kabul edilen ve kullanılan, kanunlarla düzenlenmemiş dijital bir para çeşidi" ve kripto paraların yaygınlaşmaya başlaması ile beraber para ifadesi ile yanlış anlaşılmaların önüne geçmek için "herhangi bir merkez bankası, kredi kuruluşu ya da e-para kuruluşu tarafından ihraç edilmemiş ve bazı durumlarda paraya alternatif olarak kullanılabilen varlığın sanal temsili" olarak revize edilmiştir (Üzer, 2017:9-16).

Elektronik paranın 6493 sayılı "Ödeme ve Menkul Kıymet Mutabakat Sistemleri, Ödeme Hizmetleri ve Elektronik Para Kuruluşları Hakkında Kanun” (BDDK, 2013, Kanun No.6493) mevzuatındaki tanımı ise şu şekildedir:

"Elektronik para ihraç eden kuruluş tarafından kabul edilen fon karşılığı ihraç edilen, elektronik olarak saklanan, bu Kanunda tanımlanan ödeme işlemlerini gerçekleştirmek için kullanılan ve elektronik para ihraç eden kuruluş dışındaki gerçek ve tüzel kişiler tarafından da ödeme aracı olarak kabul edilen parasal değeri" elektronik para olarak tanımlamıştır (6493 Nolu Kanun, md. 3 ç bendi). Elektronik paralar web üzerinde işlem gördükleri için sanal veya dijital para olarak da adlandırılmaktadırlar.

Dirican (2000), tezinde elektronik paranın tanımına, Türkiye'de ilk defa elektronik para arzının parasal büyüklükler içindeki yerine, zaman içerisinde kullanımlarının artacağına ve senyoraj gelirlerine olan etkisine değinmiştir (Dirican, 2000: 123-135).

Türkiye'de 2015 yılında kurulan “Ödeme ve Elektronik Para Derneği (ÖDED)” Fintek sözlüğüne göre Bitcoin kısaca "dünyada bir merkez bankası tarafından ihraç edilmeyen ve bunlarla ya da yasalarla belirlenmiş diğer resmî kurumlarla herhangi bir ilişkisi olmayan elektronik para" olarak tanımlanabilir (ODED, Fintek Sözlüğü, ET:2017). BTC kodu ile işlem gören Bitcoin, algoritmalar ile oluşturulan ve blok zincirleri teknolojisine dayalı bir kişiler arası elektronik para sistemi olarak ilk defa Satoshi Nakamoto adında sahte bir isimle, internette yayınladığı makale ile fikirsel olarak hayata geçmiştir. Kendisi tarafından da ilk defa uygulamada kullanılarak sanal olarak hayat bulmuştur (www.teknolojivefinans.com, ET:2017). Blok zincirleri (blockchain) ise kısaca "merkezi olmayan ve kişilerarası ağlarda yapılan işlemlerin kayıtlarını tutan dijital defteri kebirlerdir" (PWC, 2016, ET:2017). "Initial Coin Offering (ICO)" ise "bir projesi için fona ihtiyaç duyan bir yatırımcının bir dijital para veya anahtar ihraç ederek web ortamında halka arz etmesidir" (Chester, 2017 ve Ergen, fintechistanbul.org, $\mathrm{ET}$ :2017). Kripto para ise "internet ortamında, kişiler arasında işlem ve transfere izin veren şifreli, dağıtık ödeme sistemleridir" (Marian, 2016:923).

\section{2. Önde Gelen Borsa Endeksleri}

Borsalardaki çeşitli endeksler veya genel olarak endeksler ağırlıklı olarak fiyat hareketlerinden yola çıkarak borsaların veya finansal ürünlerin ya da ekonomik verilerin trendini izlemek amacı ile oluşturulur. TüFE gibi baz alınan bir başlangıç noktasından hareketle bir metodoloji ile hesaplanırlar. Çalışmada kullanılan borsa endeksleri aşağıda kısaca tanıtılmaktadır:

Borsa İstanbul'da Pay Piyasasında baz endeks olarak BiST100 dikkate alınmaktadır. Borsa İstanbul'un çeşitli alt piyasalarında işlem görmekte olan işlem hacmi en yüksek 100 firmanın hisse senedinin verileri dikkate alınarak hesaplanmaktadır (www.borsanedir.tv, ET:2017). Diğer borsa endekslerinin ise tanımı ve içerikleri kaynağa göre değişmeyeceğinden/fark arz etmeyeceğinden tek bir kaynaktan faydalanılarak aşağıda özetlenmektedir (gmcforex.com, ET:2017):

Dow Jones 30 endeksi, New York Stock Exchange'de işlem gören Coca-Cola, Disney, McDonald's, Nike, WalMart gibi önde gelen 30 firmanın hisseleri ile hesaplanmaktadır. Küresel sıralamada beşinci büyük borsa olarak görülen Şanghay Menkul Kıymetler Borsasında elli adet hisseden oluşan CHINA 50 endeksi Uzakdoğu'daki borsalar arasında önemli bir yere sahiptir. 100 İngiliz firmasının hisselerinin piyasa değerinden hareketle ağırlıklı olarak hesaplanan FTSE 100 endeksi Londra Borsası'nın göstergesidir. NASDAQ Borsası ("National Association of Securities Dealers Automated Quotations") teknoloji hisselerinin ağırıklı işlem gördüğü bir piyasadır, bu piyasa yerine Chicago Emtia Borsası'nın (CME) vadeli Bitcoin kontratını önce kabul etmesi ilginç bir gelişmedir (www.cmegroup.com, ET:2017). Amazon.com, Google.com, Apple gibi değeri en yüksek 100 hisse senedi ile hesaplanan NASDAQ100 endeksi önemli bir teknoloji endeksidir. Benzer şekilde 225 firmanın işlem hacmindeki yerine bakarak hesaplanan Nikkei 225 Endeksi içinde Toyota, Panasonic gibi firmaların senetleri bulunmaktadır. Son olarak, Standart and Poor's (S\&P) kredi derecelendirme kuruluşu tarafından hesaplanan S\&P 500 endeksi, ABD'deki piyasa değeri en yüksek 500 firmanın karlılık, sermaye gibi performanslarını dikkate alarak bunların hisse değerleri ile bulunmaktadır (gmcforex.com, ET:2017).

\section{LITERATÜR INCELEMESİ}

Internetin ve elektronik ticaretin gelişmesiyle birlikte online ödeme kolaylı̆̆ı sağlayan elektronik paralar günümüzde sıkça kullanılmaya başlamıştır. Zaman içerisinde sanal para, dijital para gibi kullanılan terimler arasına son yıllarda şifreleme tekniğinin farklılığı nedeni ile kripto paralar da girmiştir. Finansal piyasalarda yarattığı etki bakımından da araştırmacılar tarafından incelenmesi gereken bir konu haline gelmiştir. Literatür incelemesi yapıldığında, kripto paraları konu alan (ampirik) çalışmaların sınırı sayıda olduğu görülmektedir. Bu çalışmaların bir bölümü Tablo 1'de özetlenmiştir. 
Tablo 1: Kripto Paralara ilişskin Akademik Çalışmaların Özeti

\begin{tabular}{|c|c|c|c|c|}
\hline Yazar ve Tarih & Kapsam & Yöntem & Dönem & Sonuç \\
\hline Yermack (2013) & $A B D$ & Korelasyon & $\begin{array}{l}19.07 .2010- \\
29.11 .2013\end{array}$ & $\begin{array}{l}\text { Bitcoin-Dolar kuru, euro, sterlin, frank ve yen } \\
\text { kurlarıyla ve de altının fiyatıyla çok düşük bir } \\
\text { korelasyon sergilemektedir. }\end{array}$ \\
\hline $\begin{array}{l}\text { Baek ve Elbeck } \\
(2014)\end{array}$ & $A B D$ & $\begin{array}{l}\text { Korelasyon ve } \\
\text { Regresyon }\end{array}$ & $\begin{array}{l}\text { 2010:M07- } \\
\text { 2014:M02 }\end{array}$ & $\begin{array}{l}\text { Bitcoin'in günlük en yüksek ve en düşük fiyat } \\
\text { farkının aylık değişimi Bitcoin fiyatlarını etkiler. }\end{array}$ \\
\hline Glaser vd. (2014) & $\begin{array}{l}\text { Mt Gox } \\
\text { Bitcoin } \\
\text { Borsası }\end{array}$ & GARCH & $\begin{array}{l}01.01 .2011- \\
08.10 .2013\end{array}$ & $\begin{array}{l}\text { Kullanıcılar Bitcoin'i bir para birimi olarak değil, } \\
\text { spekülatif amaçlı bir yatırım aracı olarak } \\
\text { kullanmaktadırlar. }\end{array}$ \\
\hline Atik vd. (2015) & Türkiye & $\begin{array}{l}\text { Johansen } \\
\text { Eşbütünleşme, } \\
\text { Granger } \\
\text { Nedensellik }\end{array}$ & $\begin{array}{l}{ }^{1} \text { 2009:M06- } \\
\text { 2015:M02 }\end{array}$ & $\begin{array}{l}\text { Japon Yeni ile Bitcoin arasında tek taraflı bir } \\
\text { nedensellik ilişkisi görülmüştür. }\end{array}$ \\
\hline $\begin{array}{l}\text { Bouoiyour vd. } \\
\text { (2015) }\end{array}$ & Çin & $\begin{array}{l}\text { Granger } \\
\text { Nedensellik }\end{array}$ & $\begin{array}{l}\text { ²010:M12- } \\
\text { 2014:M06 }\end{array}$ & $\begin{array}{l}\text { Bitcoin fiyatı e-ticaret işlemlerinin, yatırımcı } \\
\text { çekiciliği ise Bitcoin fiyatının Granger nedenidir. }\end{array}$ \\
\hline Cheung vd. (2015) & $\begin{array}{l}\text { Mt Gox } \\
\text { Bitcoin } \\
\text { Borsası }\end{array}$ & $\begin{array}{l}\text { Phillips-Shi-Yu } \\
\text { Metodu }\end{array}$ & $\begin{array}{l}17.07 .2010- \\
18.02 .2014\end{array}$ & $\begin{array}{l}\text { Kısa ve uzun süreli fiyat balonları bu borsanın } \\
\text { çöküşüne sebep olan etmenlerdendir. }\end{array}$ \\
\hline Dyhrberg (2015) & $\begin{array}{l}\text { Büyük } \\
\text { Britanya }\end{array}$ & GARCH & $\begin{array}{l}19.06 .2010- \\
22.05 .2015\end{array}$ & $\begin{array}{l}\text { Bitcoin altınla benzer derecede hedge } \\
\text { yeteneğine sahiptir ve FTSE hisselerine karşı bir } \\
\text { koruma aracı olarak kullanılabilir. }\end{array}$ \\
\hline Kristoufek (2015) & Çin & $\begin{array}{l}\text { Wavelet } \\
\text { Coherence } \\
\text { Analizi }\end{array}$ & $\begin{array}{l}14.09 .2011- \\
28.02 .2014\end{array}$ & $\begin{array}{l}\text { Bitcoin hem finansal hem de spekülatif } \\
\text { özelliklere sahip eşsiz bir varlıktır. }\end{array}$ \\
\hline $\begin{array}{l}\text { Koçoğlu vd. } \\
\text { (2016) }\end{array}$ & $\begin{array}{l}8 \text { farklı } \\
\text { Bitcoin } \\
\text { Borsası }\end{array}$ & $\begin{array}{l}\text { Johansen } \\
\text { Eşbütünleşme, } \\
\text { Granger } \\
\text { Nedensellik }\end{array}$ & $\begin{array}{l}19.05 .2014- \\
06.09 .2015\end{array}$ & $\begin{array}{l}\text { Kripto paraların işlem gördüğü } 3 \text { borsa arasında } \\
\text { eşbütünleşme varken nedensellik ilişkisi } \\
\text { bulunamamıştır. }\end{array}$ \\
\hline Eswara (2017) & Hindistan & GARCH & $\begin{array}{l}04.04 .2017- \\
21.07 .2017\end{array}$ & $\begin{array}{l}\text { Bitcoin-rupi kuru, dolar kurundan pozitif, } \\
\text { sterlin ve yuan kurlarından negatif } \\
\text { etkilenmektedir. }\end{array}$ \\
\hline
\end{tabular}

Yermack (2013) paranın değişim, değer ve yatırım ve tasarruf aracı olması gibi temel üç fonksiyonundan hareketle Bitcoin'in bir para birimi olup olmadığını araştırmıştır. Yazar çalışmasında, Bitcoin'in döviz kuru volatilitesinin, yaygın olarak kullanılan para birimlerinin volatilitesinden daha yüksek olduğunu gözlemlemiştir. Bu durumun Bitcoin'in değişim aracı ve değer ölçüsü olarak kullanışlıı̆̆ını zayıflattığını belirtmiştir. Ayrıca Yermack, Bitcoin-dolar kuruyla, sterlin, frank, euro, yen kurları ve altın fiyatı arasında neredeyse sıfıra yakın bir korelasyon olduğunu tespit etmiştir (Yermack, 2013:1-22).

Baek ve Elbeck (2014) çalışmalarında ilk olarak Bitcoin ve borsa endeksinin volatilitesini kıyaslamışlar, ardından da Bitcoin getirilerini etkileyen değişkenlerin neler olduğunu araştırmışlardır. Sonuç olarak, Bitcoin'in S\&P500 Endeksi'nden 26 kat daha fazla volatiliteye sahip olduğunu saptamışlardır. Bunun yanında, kurdukları regresyon modelinde Bitcoin fiyatlarını etkileyen tek değişkenin Bitcoin'in günlük en yüksek ve en düşük fiyat farkının aylık değişimi olduğu sonucuna ulaşmışlardır (Baek ve Elbeck, 2014:30-34).

Glaser ve diğerleri (2015) kullanıcıların Bitcoin'i bir işlem aracı olarak mı yoksa bir yatırım aracı olarak mı kullandıklarını araştırmışlardır. Araştırma sonucunda yazarlar, Bitcoin'in kullanıılar için mal ve hizmet satın alma aracı olmadığını, spekülatif amaçlı bir yatırım aracı olduğunu tespit etmişlerdir (Glaser, Zimmermann ve Haferkorn, 2015:1-14).

Atik ve diğerleri (2015) çalışmalarında Bitcoin ile döviz kuru arasında bir ilişki olup olmadığını araştırmışlardır. Bu ilişkiyi incelemek için Bitcoin günlük kur fiyatları ve 6 ülkenin para birimi-Amerikan Doları paritesi eşbütünleşme ve nedensellik testleri kullanılarak analiz edilmiştir. Analiz sonuçlarına göre, Japon Yeni'nde Bitcoin ile nedensellik ilişkisine rastlanmıştır. Yönü ise Japon Yeni'nden Bitcoin'e doğrudur (Atik vd., 2015:247-262).

\footnotetext{
${ }^{1}$ Yazarlar, çalışmalarında Haziran 2009-Şubat 2015 arası günlük verileri kullanmışlardır.

${ }^{2}$ Yazarlar, çalışmalarında Aralık 2010-Haziran 2014 arası günlük verileri kullanmışlardır.
} 
Bouoiyour ve diğerleri (2015) araştırmasında Bitcoin fiyatları - elektronik ticaret işlemleri ve Bitcoin fiyatları - yatırımcı çekiciliği arasındaki ilişkiyi incelemiştir. Bitcoin fiyatları elektronik ticaret işlemlerini anlamlı olarak etkilemekte, yatırımcı çekiciliği ise Bitcoin fiyatlarını anlamlı olarak etkilemektedir (Bouoiyour, Selmi ve Tiwari, 2015:1-23)

Cheung ve diğerleri (2015) Mt Gox borsasındaki Bitcoin fiyatlarında meydana gelen volatiliteyi ve hızlı fiyat artışlarını incelemişlerdir. Araştırmada 2010-2014 arası 1307 günlük gözlem analiz edilmiş ve analiz sonucunda kısa süreli fiyat balonlarının yanında, uzun süreli üç fiyat balonu tespit edilmiştir. Bu fiyat balonlarının patlaması, Mt Gox borsasının da çöküşünü hazırlayan nedenlerden biri olmuştur (Cheung, Roca ve Su, 2015:2348-2358). Bitcoin'i ilk satan Japonya'da kurulan Mt Gox borsasının batış nedeni olarak büyük tutarda kripto paranın sistemde çalınmış/kayıp olduğu iddiası da gösterilmektedir (tr.sputniknews.com, ET:2017).

Dyhrberg (2015) 2010-2015 arası 1769 günlük verilerle Bitcoin'in fiyat değişikliklerine karşı bir hedge (riskten korunma) aracı olup olmadığını araştırmıştır. Araştırma sonucunda, Bitcoin'in piyasa riskine karşı tedbir alınması amacıyla altınla benzer özellikleri taşıdığı, FTSE endeksindeki hisse senetlerine ve kısa vadede dolara karşı bir hedge aracı olarak kullanılabileceğini ortaya koymuştur. Yazara göre, analistler Bitcoin'i de piyasa riskini önlemek için kullanılan araçlar arasına ekleyebilirler (Dyhrnerg, 2015:139-144).

Kristoufek (2015), Bitcoin fiyatlarının Çin pazarındaki potansiyel etkilerini analiz ederek Bitcoin tartışmasına katkıda bulunmuştur. Analiz sonucunda, Bitcoin'in spekülatif bir varlık olmasına rağmen, ticarette kullanılması, arz edilmesi ve fiyat seviyelerinin değişmesi gibi temel faktörlerin uzun vadeli Bitcoin fiyatlarını etkilediği gözlenmiştir. Sonuç olarak, Bitcoin'in hem standart bir finansal hem de spekülatif özelliklere sahip benzersiz bir varlık olduğuna karar vermiştir (Kristoufek, 2015:1-15)

Koçoğlu ve diğerleri (2016) Bitcoin'in işlem gördüğü 8 farklı borsanın etkinliğini, likiditesini ve volatilitesini analiz etmiştir. Araştırma sonucuna göre, Bitfinex (USD), Bitstamp (USD), Btce (USD) Bitcoin borsaları birbirleriyle eşbütünleşik, Okcoin (CNY) borsası ise bu üç borsa ile eşbütünleşik değildir. Ayrıca söz konusu Bitcoin piyasalarının kendi aralarında nedensellik görülmediği ve ilişki bulunmadığına kanaat getirilmiştir (Koçoğlu, Çevik ve Tanrı̈ven, 2016:77-97).

Eswara (2017) çalışmasında Hint Rupisi kurundan Bitcoin fiyatının dolar, euro, sterlin, yen ve yuan kurlarından etkilenip etkilenmediğini araştırmıştır. Analiz ettiği dönem 105 günlük gözlemi kapsamaktadır. Analiz sonucuna göre, Bitcoin'in rupi değeri, dolardan pozitif etkilenirken, sterlin ve yuandan negatif etkilenmektedir (Eswara, 2017:187-195).

Kripto paralar ve Bitcoin ile ilgili literatürdeki ilgili diğer çalışmalar şu şekilde özetlenebilir:

İskenderoğlu (1988) TCMB'deki tebliğinde para sistemlerini/standartlarını özetlemiş ve rezerv para/varlık sorununa değinmiştir. Doların başta ABD dış ticaret açıkları nedeni ile değer kaybının diğer ülke merkez bankalarında rezerv çeşitliliğine gitmesi sonucunu doğurduğunu belirtmiştir. Bu şekilde diğer dövizlerin kullanımı ile merkezi bir yapıdan uzaklaşılmasına neden olduğu ve kurlarda dalgalanmaları arttırdığı sonucunu doğurduğu ifade edilmiştir. Dalgalı kur rejimine geçiş dönemindeki bu benzer durumun bugün de kripto paraların tercih nedenlerine katkı sağladığını söylemek güç olmayacaktır. Rezerv çeşitliliğinin yanında ülkelerin ekonomik krizlere karşı koyduğu mevduat kontrolü, vergi gibi yaptırımları karşısında paranın mobilitesini sağlayabilmek yatırımcıların tercihini bu yöne kaydırmaktadır. Ancak kripto paralar henüz merkez bankalarının bilançosunda bir rezerv para olarak kullanılmamaktadır. Bitcoin ve benzerlerinin tarafsız olarak arzı ise merkez bankalarının bağımsızlı̆ına, ülkelerin egemenliğine bir tehdit olarak algılandığından şimdilik sayılı merkez bankalarının kendi kripto paralarını çıkarma isteğine katkı sağlamaktadır. Zaman içerisinde analitik bilançolarının her iki tarafında da yer alması söz konusu olacaktır (i̇skenderoğlu, 1988:1-31). Nitekim IMF Başkanı Christine Lagarde Londra'da düzenlenen bir konferansta dijital (kripto) paraların yasaklanmasının iyi olmayacağını, bunların para birimi istikrarsız olan ülkelerce yerli paraları yerine kullanılabileceğini ve buna dolarizasyon 2.0 adını verdiklerini söylemiştir (www.uzmancoin.com, ET:2017). Benzer bir görüşü, TCMB Başkanı Murat Çetinkaya dijital paraların finansal istikrara katkı sağlayacağı yönünde vermiştir ve TCMB nezdinde kripto paralar için bir çalışma grubu kurulduğunu bildirmiştir (www.kointurk.net, ET:2017). Ciaian, Rajcaniova ve Kancs'ın çalışmasında Bitcoin'i paranın işlevleri ile kıyaslamış, Bitcoin ile petrol fiyatları, wikipedia görüntüleme sayısı, bitcointalk.org sitesine üye olanların ve postlarının sayısı gibi birçok değişken arasında kısa ve uzun vadede ilişki ölçümlenmiş ve korelasyonları dahilinde Dow Jones ile uzun vadede yüksek korelasyon görülmüştür (Kancs, Ciaian ve Rajcaniova, 2014:1-22 ve 2015:1-46). Bu sonuç bu çalışmamızın hipotezine, analiz kısmına ve sonuçlarına yine önemli bir teyit olarak görülebilir.

Zengin ve Güngördü çalışmalarında elektronik ödeme sistemlerini ve etkilerini incelerken Bitcoin'i işlem güdüsü dahilinde diğer ödeme sistemlerinin içerisinde elektronik para türevi olarak tanımlamışlardır (Zengin ve Güngördü, 2013:129-150).

Bitcoin, kripto paralar, blockchain başlıklarında popülariteleri ile doğru orantılı olarak son yıllarda yoğun bir haber ve veri akışı bulunmaktadır. Bunlar arasından bir kısmı önemi ve bu çalışmanın ana hatları ile ilgisi bakımından şu şekilde özetlenebilir: 
Çin Bitcoin borsasının ve ICO’ları yasaklamış olmasına rağmen Çin Sanayi ve Bilişim Teknolojileri Bakanlığı Blockchain araştırma laboratuvarı kurarak bu teknolojinin kullanım alanları üzerinde çalışmalar başlatmıştır (Oktay, 2017, ET:2017). Rusya gibi Güney Kore'de ICO'ları dolandırıcılık endişesi nedeni ile yasaklayan ülkeler arasına katılmıştır (www.uzmancoin.com, ET:2017). Goldman Sachs yatırım bankası müşterilerinin yatırımlarında Bitcoin kullanması ve yatırım yapması konusunda plan yapmaktadır (Shaimardanov, 2017, ET:2017). CME'nin Bitcoin kontratlarını 2017 sonunda işleme almasının yanında Japonya'nın bu borsalara izin vermesi de önemli bir gelişmedir (www.bloomberght.com, ET:2017).

\section{VERI VE YÖNTEM}

Bu kısımda bu çalışmada yapılan analizler ile ilgili kullanılan verilere, Pesaran \& Shin \& Smith üçlüsünün 2001'de geliştirdiği "ARDL sınır testi yaklaşımı" modeline yönelik bilgiler verilmektedir (Pesaran, Shin ve Smith, 2001:289-326).

\subsection{Metodoloji}

Literatür incelendiğinde, bahsi geçen diğer çalışmalarda birbirinden farklı ekonometrik modellerin kullanıldığı görülmektedir. Bu çalışmada ise, araştırmamıza konu olan değişkenlerin ilişkisini incelemek için durağanlık kısıtı üstünlüğüne sahip olması sebebiyle, serilere ARDL (Autoregressive Distributed Lag) Testi uygulanacaktır.

Eşbütünleşme testleri, çeşitli değişkenlerin uzun veya kısa dönemdeki ilişkilerinin tespiti/incelemesi için kullanılır. Literatürde genellikle Engle \& Granger'ın (1987: 251-276), Johansen'in (1988: 231-254) ve Johansen \& Juselius'un (1990: 169-210) test yöntemleri eşbütünleşmeyi analiz etmek adına kullanılmaktadır. Bu testler, çalışmaya dâhil olan tüm serilerin ya orijinal seviyesinde ya da birinci fark seviyesinde durağan olması koşuluyla değişkenlere uygulanabilir. Seriler farklı durağanlık seviyelerinde ise, bu testleri kullanmak mümkün değildir. Buna karşın, Pesaran \& Pesaran (1997), Pesaran \& Shin (1998: 371-413) ve Pesaran ile diğerlerinin (2001: 289-326) geliştirdiği "ARDL modeli yaklaşımı", serilerin orijinal seviyede ya da birinci fark seviyesinde durağanlaşmasına bakmaksızın eşbütünleşme ilişkisinin incelenmesini mümkün kılmaktadır. Bu testin avantajı, farklı durağanlık seviyelerine sahip değişkenler arasındaki eşbütünleşme ilişkisinin analiz edilmesine izin vermesidir. Ayrıca, eşbütünleşme testleri uzun gözlemlerden oluşan bir veri setine uygulandığında daha anlamlı sonuçlar verirken, ARDL Modeli küçük örneklemlere uygulandı̆̆ında da anlamlı sonuçlar vermektedir (Pesaran ve Shin, 1998: 373).

ARDL yaklaşımı, 3 adımlı bir süreçten oluşur. İlk adımda, "ARDL Sınır Testi", değişkenlerin arasındaki uzun dönemli bir ilişki var mı sorusunu inceler. İkinci ve üçüncü adımlara değişkenlerde uzun dönemde ilişkinin görülmesi koşuluyla geçilir. " $A R D L$ Sınır Testi" ile uzun dönemde ilişkisel bir durum görülürse, sırasıyla kısa ve uzun dönemdeki katsayılara ulaşılabilir (Narayan ve Smyth, 2006: 337, 332-342).

\subsection{Veri Seti}

Bu çalışmada, çalışmanın yapıldığı dönemde (sanal) dünyada var olan 1.265 kripto para içinde en çok kullanılan ve pazar kapasitesinin \%60'ından fazlasına hâkim olan Bitcoin ele alınmıştır. Kripto para piyasaları incelendiğinde, güncel olarak 6.500 civarında borsa/piyasa olduğu gözlemlenmiştir. Bu 6.500 kripto para borsası içinde Bitcoin işlem hacmine sahip en büyük borsanın Bitfinex olduğu görülmektedir. Bundan dolayı Bitcoin fiyatlarının verileri Bitfinex borsasından ilgili web sayfasının taranması sonucu elde edilmiştir. Bitcoin'in işlem gördüğü en büyük 5 borsaya ait güncel veriler Tablo 2'de görülecektir.

Tablo 2: Bitcoin'in İşlem Gördüğü En Büyük 5 Borsa

\begin{tabular}{c|c|c|c|c|c|}
\hline$\#$ & Borsalar & Para Çiftleri & Hacim (Son 24 saatlik) & Fiyat & Hacim (\%) \\
\hline $\mathbf{1}$ & "Bitfinex" & BTC/USD & $\$ 303.034 .000$ & $\$ 7110.00$ & $11.91 \%$ \\
\hline $\mathbf{2}$ & "bitFlyer" & BTC/JPY & $\$ 153.963 .000$ & $\$ 7152.61$ & $6.05 \%$ \\
\hline $\mathbf{3}$ & "Bithumb" & BTC/KRW & $\$ 139.392 .000$ & $\$ 7362.84$ & $5.48 \%$ \\
\hline $\mathbf{4}$ & “GDAX" & BTC/USD & $\$ 129.247 .000$ & $\$ 7125.00$ & $5.08 \%$ \\
\hline $\mathbf{5}$ & "Bitstamp" & BTC/USD & $\$ 98.865 .400$ & $\$ 7116.02$ & $3.89 \%$ \\
\hline
\end{tabular}

Kaynak: https://coinmarketcap.com/currencies/bitcoin/\#markets (Erişim Tarihi: 07.11.2017)

Dünyanın en çok işlem hacmine sahip ve değerli (hisse senedi) borsalarına ait başlıca endeksler, Bitcoin fiyatlarını etkilediği ya da tersi söz konusu olabileceği düşüncesiyle çalışmaya dahil edilmiştir. Bunlar DOW30, NASDAQ100, FTSE100, NIKKEI225 ve CHINAA50 endeksleridir. Bu endekslerin borsalarına ait bilgilere ve firma sayılarına Tablo 3'te yer verilmiştir. 
Tablo 3: Dünyanın En Büyük 5 Borsası

\begin{tabular}{c|c|c|c|c|c|}
\hline$\#$ & Borsalar & $\begin{array}{c}\text { Piyasa Değeri } \\
\text { (Milyar \$) }\end{array}$ & $\begin{array}{c}\text { Ömrü } \\
\text { (Yıl) }\end{array}$ & $\begin{array}{c}\text { Firma } \\
\text { SayısI }\end{array}$ & Endeksler \\
\hline $\mathbf{1}$ & "New York Stock Exchange" & 19,223 & 224 & 2400 & DOW30 \\
\hline $\mathbf{2}$ & "National Association of Securities Dealers Automated \\
Quotations (NASDAQ)" & 6,831 & 45 & 3058 & NASDAQ100 \\
\hline $\mathbf{3}$ & "London Stock Exchange" & 6,187 & 215 & 3041 & FTSE100 \\
\hline $\mathbf{4}$ & "Tokyo Stock Exchange" & 4,485 & 138 & 2292 & NIKKEI225 \\
\hline $\mathbf{5}$ & "Shanghai Stock Exchange" & 3,986 & 26 & 1041 & CHINAA50 \\
\hline
\end{tabular}

Kaynak: http://www.visualcapitalist.com/20-largest-stock-exchanges-world/(Erişim tarihi: 07.11.2017)

Not: 10.04.2017 tarihli paylaşımdır.

Dünyanın en çok işlem hacmine sahip ve önde gelen 5 büyük borsasının hisse senedi endekslerine ek olarak, ABD merkezli, Standard \& Poor's (S\&P) (tarafsız ve bağımsız bir "kredi derecelendirme kuruluşu") tarafından hesaplanan, Amerika Birleşik Devletleri'ndeki en büyük 500 firmayı içeren S\&P500 endeksi de analize dahil edilmiştir. Tüm bu endekslerin yanında, Borsa İstanbul'a ait BIST100 endeksi de analize eklenerek, Bitcoin fiyat hareketleri ile Türkiye'de Borsa İstanbul BisT100 Endeksi ile arasında bir eşbütünleşme ilişkisi bulunup bulunmadığı da araştırılmıştır.

Bu çalışma kapsamında diğer borsa endekslerinin, teknoloji, bankacılık gibi alt endekslerinin veya petrol, altın gibi diğer yatırım enstrümanlarının ya da Ethereum gibi diğer kripto paraların neden analize dahil edilmediği sorulabilir. Bitcoin'in en fazla işlem gören kripto para olması ilk sebeptir. Ayrıca çalışmanın bir rapordan veya tezden çok makale olması nedeni ile uzunluk kriteri de dikkate alınmıştır. Yine salt hisse senedi endeksleri olmasının nedeni emtia olarak değerlendirilmek istenmemesindendir. Benzer şekilde ödeme sistemi, para, e-ticaret gibi diğer fonksiyonlar da kapsam dışı bırakılmıştır.

Çalışmada yer alan bu toplam 8 değişkene ait veri seti, 24 Mayıs 2013 - 05 Kasım 2017 tarihleri arası haftalık 206 gözlemden oluşmaktadır. Veriler bu tarih aralığındaki ilgili endekslerin borsa/piyasa kapanış değerleridir, Bitcoin içinse ilgili borsa/piyasa işlem fiyatıdır. Tüm verilere https://tr.investing.com/ internet sitesi üzerinden 06.11.2017 tarihinde ulaşılmıştır (tr.investing.com, ET:2017).

Çalışmada verilerin ham formları yerine verilerin logaritmik formları kullanılacaktır. Logaritmik dönüşüm yapılmasının nedeni, belirli bir tabana göre logaritma alarak değişkenleri küçültmektir. Logaritmik dönüşüm sonucunda, orijinal veriler küçülür ve herhangi bir bilgi kaybı yaşanmaz. Ayrıca logaritmik dönüşüm otokorelasyon sorununu azaltır ve serilerin normal dağılım sergilemesini arttırır.

\section{ANALIZ VE UYGULAMA}

Veri setine yönelik bu bilgiler ışığında analizin ilk aşaması olan birim kök testine geçilmiştir. Durağanlık analizi sonrası ARDL testine geçilmiştir. Analizler EViews 9.0 programı ile yapılmıştır (www.eviews.com). Bitcoin fiyatları ile söz konusu borsa hisse senedi piyasa endeks değerleri arasında bir eşbütünleşme ilişkisi olup olmadığı analiz edilmiştir. Analizlerde ilgili piyasalardaki/borsalardaki analize denk dönemlere ait işlem hacimleri veya ilgili finansal varlıkların arz miktarları makalenin kapsamının dar tutulmak istenmesi nedeni ile dahil edilmemiştir. Buna bir diğer neden olarak yatırımcı kararlarında öncelikle getirilerin dikkate alınması ve bu çalışmanın dönemi itibarı ile hızlı yükselen Bitcoin fiyatlarının yatıımcılar nezdindeki cazibe ve ilgisinin yüksek olması, keza yine benzer şekilde başta ABD olmak üzere dünya borsalarının 2016 Kasım $A B D$ seçimlerinden sonra hızla yükselmesi gösterilebilir.

\subsection{Birim Kök Testi Sonuçları}

Durağanlık, zaman serileri ile yapılacak analizlerde genellikle test edilmesi gereken bir durumdur. Çalışmada, zaman serilerinin durağanlığını sınamak için yapısal kırılmalı birim kök testi tercih edilmektedir. Uygulanacak olan ARDL testine geçmeden önce, değişkenlerin durağan olup olmadıkları kontrol edilecektir. Bu doğrultuda uygulanan yapısal kırılmalı birim kök testinin ayrıntıları Tablo 4'teki gibi sunulmuştur.

Tablo 4: Yapısal Kırılmalı Birim Kök Testi Sonuçları

\begin{tabular}{c|c|c|c|c|}
\hline \multirow{2}{*}{ Değişkenler } & \multicolumn{2}{|c|}{ Orijinal Düzey } & \multicolumn{2}{c|}{ Birinci Sıra Fark Düzeyi } \\
\cline { 2 - 5 } & Test İstatistiği & Olasılık & Test İstatistiği & Olasılık \\
\hline LOGBITCOIN & -2.004076 & $>0.99$ & -17.23498 & $<0.01$ \\
\hline LOGCHINAA50 & -3.192071 & 0.8482 & -14.63735 & $<0.01$ \\
\hline
\end{tabular}




\begin{tabular}{c|c|c|c|c}
\hline LOGBIST100 & -3.495686 & 0.6947 & -15.48117 & $<0.01$ \\
\hline LOGDOW30 & -3.756762 & 0.5279 & -16.52989 & $<0.01$ \\
\hline LOGFTSE100 & -4.179722 & 0.2697 & -15.93945 & $<0.01$ \\
\hline LOGNASDAQ100 & -4.332335 & 0.1954 & -16.42736 & $<0.01$ \\
\hline LOGNIKKEI225 & -4.465734 & 0.1430 & -16.01211 & $<0.01$ \\
\hline LOGS\&P500 & -5.034802 & 0.0297 & & \\
\hline \%1: Test istatistiği $i=-5.347598$ & & \\
\hline \%5: Test istatistiği $i=-4.859812$ \\
\hline \%10: Test istatistiği $=-4.607324$
\end{tabular}

Tablo 4'teki yapısal kırılmalı birim kök testi sonuçlarına göre, ilk yedi değişkenin orijinal düzey olasılık değerleri 0.05 'ten büyüktür. Bu durum, söz konusu değişkenlerin orijinal düzeyde durağan olmadıkları anlamına gelir. Birinci sıra fark seviyesinde, bu değişkenlerin olasılık değerlerinin 0.05 'ten küçük olmaları, bu düzeyde durağanlaştıklarının işaretidir. Kullanılan yöntemin serilerin durağanlaşma seviyelerini önemsememesi sebebiyle, çalışmada bu değişkenlerin birinci sıra fark değerleri kullanılacaktır. Buna karşın, yalnızca logaritması alınmış S\&P500 değişkeni orijinal düzeyde durağandır. Bu değişkenin olasııık değerinin 0.05 'ten küçük olması onun orijinal seviyede durağan olduğunun kanıtıdır. Çalışmaya konu olan değişkenlerin bir tanesinin orijinal düzeyde, yedi tanesinin ise birinci sıra fark düzeyinde durağan olması, araştırma için uygun bir modelin tercih edildiğinin göstergesidir. Çalışma eşbütünleşmenin incelenmesi için ARDL yaklaşımıyla devam edecektir.

\subsection{ARDL Testi Sonuçları}

Araştırmada kullanılacak yöntemin uygun olduğuna karar verildikten sonra, ilk adım olarak, tahmin edilecek ARDL modelinin en uygun gecikme uzunluğu belirlenmelidir. VAR modeli kurularak belirlenen en uygun gecikme uzunluğuna ilişkin ayrıntılar Tablo 5'te gösterilmektedir.

Tablo 5: VAR Modeli İçin En Uygun Gecikme Uzunluğunun Belirlenmesi

\begin{tabular}{c|c|c|c|c|c|c|}
\hline Gecikme & LogL & LR & FPE & AIC & SC & HQ \\
\hline 0 & 2288.333 & NA & $1.37 \mathrm{e}-20$ & -23.03367 & -22.90081 & -22.97989 \\
\hline $\mathbf{1}$ & 4192.982 & $\mathbf{3 6 3 6 . 1 4 9 *}$ & $\mathbf{1 . 1 5 e - 2 8 *}$ & $\mathbf{- 4 1 . 6 2 6 0 8 *}$ & $\mathbf{- 4 0 . 4 3 0 3 \mathbf { F } ^ { * }}$ & $\mathbf{- 4 1 . 1 4 2 0 9 *}$ \\
\hline 2 & 4236.473 & 79.51259 & $1.42 \mathrm{e}-28$ & -41.41892 & -39.16031 & -40.50471 \\
\hline 3 & 4274.772 & 66.92694 & $1.86 \mathrm{e}-28$ & -41.15931 & -37.83783 & -39.81489 \\
\hline 4 & 4305.126 & 50.58977 & $2.65 \mathrm{e}-28$ & -40.81945 & -36.43510 & -39.04481 \\
\hline 5 & 4337.535 & 51.39670 & $3.73 \mathrm{e}-28$ & -40.50035 & -35.05312 & -38.29550 \\
\hline 6 & 4378.623 & 61.83993 & $4.88 \mathrm{e}-28$ & -40.26892 & -33.75882 & -37.63385 \\
\hline 7 & 4427.256 & 69.26421 & $5.99 \mathrm{e}-28$ & -40.11369 & -32.54072 & -37.04840 \\
\hline 8 & 4482.898 & 74.75234 & $6.97 \mathrm{e}-28$ & -40.02928 & -31.39342 & -36.53377 \\
\hline
\end{tabular}

Not: "*” kriterlerin işaret ettiği en uygun gecikme uzunluğunu gösterir.

LR: Ardışık modifiye edilmiş LR test istatistiği (her test \%5 seviyesinde)

FPE: Son tahmin hatası

AIC: Akaike bilgi kriteri

SC: Schwarz bilgi kriteri

HQ: Hannan-Quinn bilgi kriteri

$F P E, A I C, S C$ ve $H Q$ gibi kritik değerler VAR modelindeki en uygun gecikme uzunluğu durumunun belirlenmesine yardımcı olurlar. FPE, AIC, SC ve HQ için en küçük değeri veren gecikme sayısı, en uygun gecikme uzunluğudur. Tablo 5 incelendiğinde tüm bilgi kriterleri birinci gecikmeyi en uygun gecikme uzunluğu olarak seçmektedir. Fakat birinci gecikmenin en uygun gecikme uzunluğu olduğunu söyleyebilmek için bu gecikmede otokorelasyon olup olmadığı kontrol edilmelidir. Otokorelasyon, LM testi ile sınanmıştır ve testin detayları aşağıdaki gibi yer almıştır. 
Tablo 6: LM Testi

\begin{tabular}{c|c|c|}
\hline Gecikme & LM istatistik & Olasılık \\
\hline $\mathbf{1}$ & $\mathbf{6 7 . 7 9 6 1 4}$ & $\mathbf{0 . 3 4 9 1}$ \\
\hline 2 & 72.27653 & 0.2235 \\
\hline 3 & 49.44613 & 0.9097 \\
\hline
\end{tabular}

Tablo 6'da, VAR modelinin birinci gecikmesinde LM testi olasılık değerlerinin 0.05 'ten büyük olduğu görülmüştür. Görülen durum, birinci gecikmede otokorelasyon olmadığını ifade eder. Ayrıca modelde değişen varyans sınaması da yapılmış ve modelde değişen varyans bulunmadığını saptanmıştır. Böylelikle VAR modelimiz için en uygun gecikme uzunluğunun birinci gecikme uzunluğunda olduğu kesin bir şekilde kanıtlanmıştır.

En uygun gecikme uzunluğu belirlendikten sonra, ARDL modelinin tahminine geçilebilir. Modelin tahminine ilişkin detaylar Tablo 7 üzerinden aktarılmaktadır.

Tablo 7: ARDL (1, 0, 0, 0, 0, 0, 1, 0, 0) Modeli Tahmin Sonuçları

\begin{tabular}{|c|c|c|c|c|}
\hline Değişkenler & Katsayı & Std. Hata & t-i̇statistik & Olasılık \\
\hline LOGBITCOIN[-1] & 0.887741 & 0.027481 & 32.30352 & 0.0000 \\
\hline LOGBIST100 & 0.182753 & 0.120596 & 1.515412 & 0.1313 \\
\hline LOGCHINA50 & -0.211369 & 0.084187 & -2.510711 & 0.0129 \\
\hline LOGDOW30 & 2.279602 & 0.806832 & 2.825374 & 0.0052 \\
\hline LOGFTSE100 & 0.034666 & 0.217480 & 0.159400 & 0.8735 \\
\hline LOGNASDAQ100 & 0.747106 & 0.366007 & 2.041234 & 0.0426 \\
\hline LOGNIKKEI225 & -0.540214 & 0.274334 & -1.969185 & 0.0504 \\
\hline LOGNIKKEI225[-1] & 0.454082 & 0.259085 & 1.752635 & 0.0812 \\
\hline LOGS\&P500 & -2.550756 & 1.105643 & -2.307035 & 0.0221 \\
\hline KUKLADEGISKEN & -0.058015 & 0.021537 & -2.693776 & 0.0077 \\
\hline C & -7.980939 & 1.948180 & -4.096611 & 0.0001 \\
\hline$R^{2}$ & 0.987527 & \multicolumn{2}{|c|}{ Mean dependent var } & 6.421168 \\
\hline Adjusted $R^{2}$ & 0.986884 & \multicolumn{2}{|c|}{ S.D. dependent var } & 0.826161 \\
\hline S.E. of regression & 0.094617 & \multicolumn{2}{|c|}{ Akaike info criterion } & -1.825794 \\
\hline Sum squared resid & 1.736761 & \multicolumn{2}{|c|}{ Schwarz criterion } & -1.647486 \\
\hline Log likelihood & 198.1439 & \multicolumn{2}{|c|}{ Hannan-Quinn criterion } & -1.753672 \\
\hline F-statistic & 1535.923 & \multicolumn{2}{|c|}{ Durbin-Watson criterion } & 2.276040 \\
\hline Prob (F-statistic) & 0.000000 & & & \\
\hline
\end{tabular}

Bağımlı Değişken: LOGBITCOIN

Not: Köşeli parantez içindeki veriler, gecikme süresini temsil etmektedir.

Tablo 7'den görüleceği üzere, $R^{2}$ ve Düzeltilmiş $R^{2}$ değerleri son derece yüksektir ve F-istatistik değeri modelin bütünsel şekilde anlamlı olduğunu göstermektedir. Ayrıca, modelde yapısal bir kırılma olup olmadığı Brown ve diğerleri (1975) tarafından geliştirilen ${ }^{3}$ CUSUM testi ile tespit edilmelidir (Brown vd. 1975: 149 -192). Yapısal bir kırılma gözlenirse, kırılmanın gerçekleştiği aralık ya da aralıklar için kukla değişken oluşturulmalıdır. Oluşturulan kukla değişkenin yapısal kırılmayı yok etmesi beklenir. CUSUM testinin sonucu Şekil 1'den görülmektedir.

\footnotetext{
${ }^{3}$ "CUSUM testi " $n$ " gözlem sayısıyla ilişkili kümülatif hata terimine dayanır ve \%5 anlam düzeyinde iki kritik çizgi arasına çizilen bir eğriyi gösterir. Eğri iki kritik sınır arasında bulunuyorsa, tahmin edilen katsayıların uzun vadede istikrarlı olduğu sonucuna varıır."
} 
Şekil 1: Cusum Testinin Sonucu
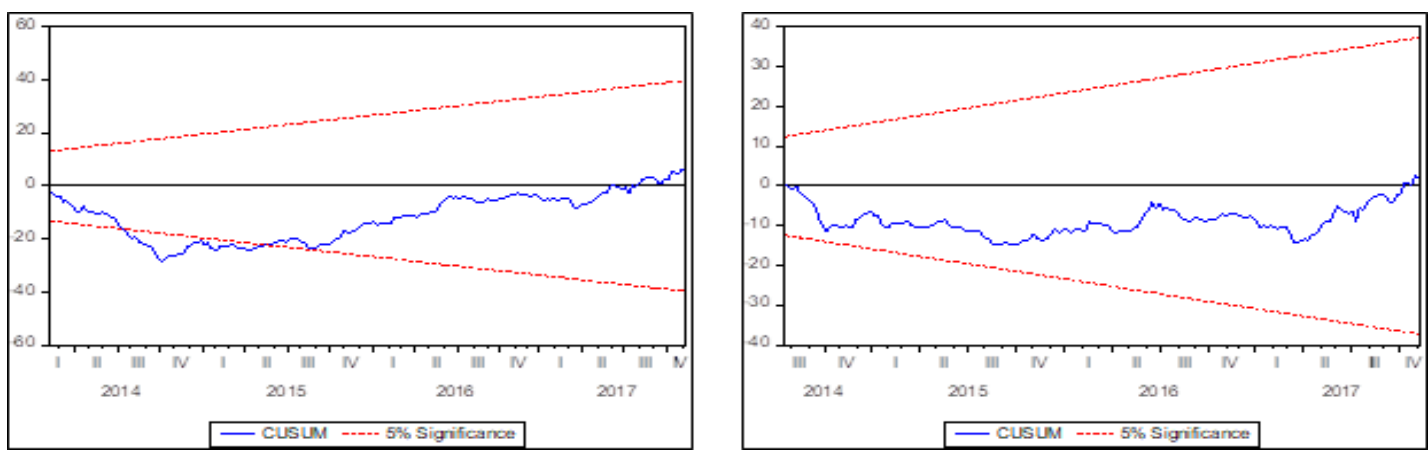

Şekil 1 (Sol) incelendiğinde, modelde yapısal bir kırılma olduğu tespit edilmiştir. Bu nedenle, kırılmanın gerçekleştiği 13.07.2014 - 17.05.2015 arası dönem için bir kukla değişken oluşturulup modele eklenmelidir. Tablo 7'de modele eklenmiş olan kukla değişkenin olasılık değeri 0.05 'den küçüktür. Bu durum, kukla değişkenin istatistiksel olarak anlamlı olduğunu gösterir. Bunun yanında, kukla değişkenin yapısal kırılma sorununu çözdüğü Şekil 1 (Sağ)'den anlaşılmaktadır. CUSUM testinden sonra, tanısal testlerle modelin uygunluğu araştırılmıştır. Tanısal testlerin sonuçları Tablo 8'de özetlenmiştir.

Tablo 8: Tanısal Testlerin Sonuçları

\begin{tabular}{c|c|}
\hline Testler & Olasılık \\
\hline Ramsey RESET Testi & 0.2759 \\
\hline Normallik Testi & 0.1093 \\
\hline Breusch-Godfrey Seri Korelasyon LM Testi & 0.1504 \\
\hline Değişen Varyans Testi: White & 0.1332 \\
\hline
\end{tabular}

Tablo 8 modelin uygun ve sorunsuz olduğunu göstermektedir. Testlerin sonuçlarına göre, model sapmasız ve tutarlıdır. Tanısal testlerin ardından, öncelikle uzun dönemli ilişki olup olmama durumunu test edebilmek adına değişkenlere " $A R D L$ Sınır Testi" uygulanacaktır. Bu adımda, serilerin birbirleriyle uzun dönemli ilişkisinin tespit edilmesi için F-istatistiği değerine ihtiyaç duyulmaktadır. Tablo 9 ARDL Sınır Testimizin sonuçlarını göstermektedir.

Tablo 9: ARDL (1, 0, 0, 0, 0, 0, 1, 0, 0) Sınır Testi Sonuçları

\begin{tabular}{c|c|c|c|c|}
\hline F-istatistik & $\mathbf{k}$ & Anlamlılık Düzeyi & Alt Sınır & Üst Sınır \\
\hline \multirow{3}{*}{3.871211} & \multirow{3}{*}{8} & $\% 10$ & 1.85 & 2.85 \\
\cline { 2 - 4 } & \multirow{2}{*}{$*$} & $\% 5$ & 2.11 & 3.15 \\
\cline { 2 - 4 } & & $\% 1$ & 2.62 & 3.77 \\
\hline
\end{tabular}

Not: "k" bağımsız değişken sayısını temsil etmektedir.

Hesaplanan " "F-istatistik değeri” ile Pesaran ve diğerlerinin (2001) çalışmasındaki "tablo kritik değerleri" karşılaştırılmıştır. Tablo 9'a göre, F-istatistik değeri, tüm anlamlılık düzeylerinde üst sınırların da üzerindedir. Bu bulgu, değişkenler arasında uzun dönemli eşbütünleşmenin görüldüğü anlamına gelmektedir. Seriler arasındaki eşbütünleşme ilişkisi ispatlandığından, sırasıyla kısa ve uzun dönemdeki katsayıların belirlenmesi işlemine geçilebilir. Kısa dönemli katsayıların sonuçları Tablo 10 'da gösterilmiştir.

Tablo 10: ARDL (1, 0, 0, 0, 0, 0, 1, 0, 0) Modeli Kısa Dönem Katsayıları

\begin{tabular}{|c|c|c|c|c|}
\hline Bağımsız Değişkenler & Katsayı & Std. Hata & t-istatistik & Olasılık \\
\hline D(LOGBIST100) & -0.091647 & 0.242376 & -0.378120 & 0.7058 \\
\hline D(LOGCHINAA50) & -0.141189 & 0.197603 & -0.714506 & 0.4758 \\
\hline D(LOGDOW30) & -0.213271 & 1.782766 & -0.119629 & 0.9049 \\
\hline
\end{tabular}

\footnotetext{
4 “ARDL Sınır testinde hesaplanan F-istatistik değerinin üst sınır üzerinde olması, uzun dönemde eşbütünleşme iliş̧isi bulunduğunu işaret eder."
} 


\begin{tabular}{c|c|c|c|c|}
\hline D(LOGFTSE100) & -0.210640 & 0.545162 & -0.386381 & 0.6996 \\
\hline D(LOGNASDAQ100) & 0.053898 & 0.878269 & 0.061368 & 0.9511 \\
\hline D(LOGNIKKEI225) & -0.549313 & 0.297548 & -1.846134 & 0.0664 \\
\hline D(LOGS\&P500) & 1.284195 & 2.460624 & 0.521898 & 0.6023 \\
\hline D(KUKLADEGISKEN) & -0.015549 & 0.066909 & -0.232397 & 0.8165 \\
\hline CointEq(-1) & -0.122651 & 0.019538 & -6.277433 & $\mathbf{0 . 0 0 0 0 *}$ \\
\hline
\end{tabular}

Bağımlı Değişken: LOGBITCOIN

Not: "*” \%5 istatistiksel anlamlılı seviyesini temsil etmektedir.

Tablo 10'daki "CointEq(-1)" eşbütünleşme katsayısını temsil etmektedir. Bu katsayı, serilerin uzun dönemli ilişkisindeki hata terimlerinin bir dönem önceki gecikmesini içeren değeridir ve kısa dönemdeki dengesizliğin ne oranda uzun dönem içerisinde düzeltilebileceğini göstermektedir. Başka bir deyişle, hata düzeltme teriminin katsayısı olarak tanımlanabilir. Bulunan katsayının negatif ve istatistiksel olarak anlamlı olması beklenir. Tablo 10'daki modelin sonuçları incelendiğinde, hata düzeltme teriminin katsayısı negatif ve olasılık değeri 0.05 'ten küçüktür. Buna göre, katsayı istatistiksel olarak anlamlıdır. Ayrıca, katsayının negatif değerde ve anlamlı olmasının eşbütünleşme ilişkisini de desteklediği görülmektedir. Hata düzeltme katsayısı, bir şokun ya da olağanüstü bir etkinin gerçekleşmesi durumunda, kısa ve uzun dönem arasındaki dengesizliğin, bir sonraki dönemde yaklaşık \%12 oranında düzeltileceğini ifade etmektedir. Buna ek olarak, ilgili borsa endekslerinin kısa dönem katsayıları incelendiğinde, hiçbiri istatistiksel olarak anlamlı değildir. Buna göre, Bitcoin fiyatıyla çalışmada yer alan borsa endeksleri arasında kısa dönemde bir etkileşimin olmadığı sonucuna varılmıştır. Kısa dönem tahmininden sonra, Bitcoin fiyatı ile borsa endeksleri arasındaki uzun dönemli ilişkiye dair detaylar Tablo 11 'de izlenmektedir.

Tablo 11: ARDL (1, 0, 0, 0, 0, 0, 1, 0, 0) Modeli Uzun Dönem Katsayıları

\begin{tabular}{|c|c|c|c|c|}
\hline Bağımsız Değişkenler & Katsayı & Std. Hata & t-ístatistik & Olasılık \\
\hline LOGBIST100 & 1.627948 & 1.070181 & 1.521190 & 0.1298 \\
\hline LOGCHINAA50 & -1.882864 & 0.730903 & -2.576079 & $\mathbf{0 . 0 1 0 7 *}$ \\
\hline LOGDOW30 & 20.306544 & 4.867686 & 4.171704 & $\mathbf{0 . 0 0 0 0 *}$ \\
\hline LOGFTSE100 & 0.308805 & 1.926290 & 0.160311 & 0.8728 \\
\hline LOGNASDAQ100 & 6.655172 & 2.778646 & 2.395114 & $\mathbf{0 . 0 1 7 6 *}$ \\
\hline LOGNIKKEI225 & -0.767265 & 1.332556 & -0.575785 & 0.5654 \\
\hline LOGS\&P500 & -22.721969 & 7.463332 & -3.044480 & $\mathbf{0 . 0 0 2 7} *$ \\
\hline KUKLADEGISKEN & -0.516796 & 0.194310 & -2.659648 & 0.0085 \\
\hline C & -71.093678 & 12.110864 & -5.870240 & 0.0000 \\
\hline
\end{tabular}

Bağımlı Değişken: LOGBITCOIN

Not: “*” \%5 istatistiksel anlamlılık seviyesini temsil etmektedir.

Tablo 11'de CHINAA50, DOW30, NASDAQ100 ve S\&P500 endekslerinin uzun dönemde \%5 seviyesinde istatistiksel olarak anlamlı oldukları görülmektedir. Bu durum, Bitcoin'in fiyatıyla, CHINAA50, DOW30, NASDAQ100 ve S\&P500 endeksleri arasında uzun dönemli bir eşbütünleşme ilişkisi olduğu anlamına gelmektedir. Uzun dönemde, CHINAA50 ve S\&P500 endeksleri yükseldikçe Bitcoin fiyatı azalmakta; DOW30 ve NASDAQ100 endeksleri yükseldikçe Bitcoin fiyatı artmaktadır.

\section{BULGULAR VE TARTIŞMALAR}

Bitcoin, sayıları her geçen gün artan kripto paralar arasında fiyat artışı ve volatilitesi ile en çok ilgi çeken finansal varlıktır. Kripto paraların hızlı gelişimi, popülerliği ve piyasa verilerinin adetsel çokluğu nedeni ile bu çalışmada tek başına Bitcoin bağımlı değişken olarak incelenmiştir. Kripto paraların finansal bir varlık olup olmadığı konusunda ilk dönemlerde piyasalarda bir kafa karışıklı̆ı varken, günümüzde para, yatırım, ödeme enstrümanı, emtia olup olmadığı konusunda çeşitli tartışma ve çalışmalar bulunmaktadır. Bu çalışmada gerek konunun derinliği gerekse farklı boyutlar nedeni ile Bitcoin'in öncelikle yatırım boyutu değerlendirilmektedir. Literatürde Bitcoin ve kripto paralar üzerine yapılan akademik analizlerde bu çalışmanın konusu olan hisse senetleri piyasası endeks değerleri ile Bitcoin arasında bir nedensellik, korelasyon, eşbütünleşme gibi ilişkisel salt bir çalışma görülemediğinden bu çalışmanın yapılmasına karar verilmiştir. 
Bu doğrultuda ilk bulgu ve tartışma olarak Bitcoin ve/veya kripto paralar ile aşağıdaki bağımsız değişkenler/konular arasında tekli veya çoklu olmak üzere ampirik ve ekonometrik araştırmaların yapılmasının ve yine aşağıdaki bu başlıklarda kuramsal ve kavramsal çalışmaların literatüre önemli katkı yapacağı ileri sürülmektedir:

a. Yatırım Boyutundan

1. Diğer Borsa İstanbul (BIST) Pay Endeksleri ile bu çalışmadakine benzer bir analiz yapılması

2. Borsalardaki ve Bitcoin işlem hacimleri ve pazar değerleri ile aralarındaki ilişkinin değerlendirilmesi

3. Hisse senedi halka arzları ile ICO kripto para halka arzları arasındaki benzerliklerin incelenmesi

4. Organize borsalarda vadeli veya spot piyasalarda kripto paraların işlem görmesi durumu

5. Portföy teorileri ve davranışsal finans boyutundan kripto paraların incelenmesi

6. Temettü ödemesi, Takasbank, emeklilik ve yatırım fonlarında kripto paraların yeri ve kullanımı

b. Para Arzı, Para Sistemleri/Standartları ve Emtia Boyutundan

1. Dolar, Euro, Pound, Japon Yeni, Ruble, Türk Lirası gibi para birimlerinin arzı ile Bitcoin ve kripto paraların arz ilişkisi

2. Kripto para standardının altın standardı veya ons tanımı ile oluşan Dolar standardının yerine geçip geçmediği

3. Emisyon dışında Chicago, Gurley-Shaw Yaklaşımları ışığında kripto (elektronik) paraların arz tanımlarında yeri

4. Merkez bankacılığının ve senyoraj gelirlerinin geleceği, analitik bilançoda, enflasyon ve faizde kripto paranın yeri

5. Kaydi para sistemi, para ikamesi gibi kavramlar ile kripto paraların örtüşmesi

6. Merkez bankalarının para piyasası ve bankalararası para piyasalarında işlem görmesi durumu

c. Ödeme Sistemleri ve E-Ticaret Boyutundan

1. E-Ticaretteki sanal kredi kartları ödeme hacmi ile kripto para hacmi arasındaki ilişki

2. Internet bankacılığı ve mobil bankacılık kullanıcı sayıları ile kripto para hacmi, kullanıcı sayısı arasındaki ilişki

3. 6493 Sayılı Kanun kapsamında ödeme sistemlerinde regülasyon düzeltmesi ve geliştirilmesi

4. Bankacılıktaki EFT, akreditif, çek gibi ödeme enstrümanları yerine kripto para kullanımının değerlendirilmesi

5. Nesnelerin interneti gibi teknolojiler ışığında gelişecek yeni ödeme formatlarına olan etkisi açısından incelenmesi

6. Uzay teknolojileri kapsamında galaktik ödeme yöntemleri açısından kavramsal olarak incelenmesi

İkinci bulgu olarak mevzuat geliştirme ihtiyacı görülmektedir. Türkiye Cumhuriyet Merkez Bankası tarafından (TCMB) blockhain teknolojisinin araştırılması üzerine bir çalışma grubu kurulmuştur. Ödeme sistemleri ve para arzı boyutunun dışında regülasyon boyutundan da konunun değerlendirilmesi ihtiyacı bulunmaktadır. Dünyada merkez bankalarının bankacılık sistemindeki ayrıca regülatör konumu dikkate alındığında kendilerinin dışında arz edilen bir finansal varlığın para ve ödeme enstrümanı olarak da kullanılması konuyu ayrıca önemli kılmaktadır. Türkiye'de ise "Sermaye Piyasası Kurumu, Bilgi Teknolojileri ve Illetişim Kurumu, T.C. Maliye Bakanlığı Gelirler Genel Müdürlüğü, Bankacılık Düzenleme ve Denetleme Kurumu" konunun diğer düzenleyici kurumları olarak bulunmaktadır. Özellikle kripto paralara kumar, bahis, kara para, mali suçlar gibi başlıklarda atfedilen kolaylaştırıcı ve özendirici olduğu iddiaları nedeni ile Türkiye özelinde tüm bu kurumlar nezdinde yeknesak bir regülasyon ihtiyacı doğurduğu açıktır. Özellikle 6493 sayılı kanunumuz kapsamında yeni düzenleme ihtiyacının olduğu aşikârdır. Mevcut kanun elektronik paranın ihracı ve ödeme enstrümanı olarak kullanılması için ihraç eden kuruluşun şirket şekil şartları, teminat durumu, sermaye yapısı gibi konuları ele almaktadır. Kanunumuzda elektronik paranın kredi boyutu bulunmaz iken ihracı bono, mevduat gibi tamamen bir finansal karşılığa bağlanmıştır ve bu haliyle merkez bankacılığının para arzını baz almıştır. Oysa blockchain teknolojisine dayalı kripto paralar ve Bitcoin arz edilmesi boyutundan çok farklı bir finansal varlıktır, arzı başka finansal varlıklara veya merkez bankalarına bağlı değildir. Keza elektronik paranın kullanımına dair yasal taban ve uygulama boyutu bankacılık dışındaki regülatörlerde neredeyse hiç tanımlanmamıştır. Bitcoin'in ve diğer kripto paraların dayandığı blockchain teknolojisi ise noterlik makamının, yeddi eminlik yerine geçebilecek şekilde birçok ticari ve finansal işlemi kapsayacak şekilde geniş kullanım alanı olan bir başlıktır. Nitekim dünyanın önde gelen teknoloji, danışmanlık firmaları ile Bitcoin'in en çok işlem gördüğü Bitfinex'in aralarında bulunduğu "Akıllı Sözleşmeler Birliği” Washington merkezli "Dijital Ticaret Odası" önderliğinde kurulmuştur (www.fintechistanbul.org, ET:2017)

Üçüncü bulgu ve tartışma konusu olarak yeni gelişen teknolojiler boyutundan, nesnelerin interneti, yapay zekâ, çok boyutlu yazıcılar, yapay sinir ağları ve büyük veri, bulut yazılım başlıkları ışığında işin teknik boyutlarından da kripto paraların analiz edilmesinde fayda bulunmaktadır. Örneğin, nesnelerin interneti dahilinde iki farklı piyasanın ana serverlarının (bilgisayarlarının) birbirleri ile konuşması halinde, ki yapay zekalı iki makinenin kendi aralarında bir dil geliştirdiği dikkate alındığında, insider trading (içeriden öğrenenlerin ticareti), manipülasyon, asimetrik enformasyon gibi yatırım ve borsacılık kavramlarının uygulamada yeni zorluklar ve tartışmalar yaratacağı açıktır. Sosyal medyanın yatırımcı davranışlarını etkilediği ve portföy teorilerinde "social influence" ile yeni bir kavram doğurduğu aşikardır. Bu bilgiler ışığında öğrenen makinelerin, algoritmaların kripto paralara yatırım yapması veya birbirlerini yatırım boyutundan tetiklemesi, sosyal medyada kripto paralar ile ilgili haberlerin yaygınlaşmasının frekans, etkinlik, korelasyon, yatırım kararı ölçümü yapan model, web sitesi ve analizleri nasıl etkileyebileceği özellikle incelenmesi gereken başlıklar arasındadır. Bir örnekle açıklamak gerekirse yatırım kapsamlı bilgilendirme web sitelerinin veya sosyal medya hesaplarının chatbot veya yapay zeka destekli çalışması durumunda, bu makinelerce manipülatif olarak çıkartılan bir asimetrik enformasyonun kripto paraya olan talebi doğurması, 
arttırması karşılığında hisse senedi piyasalarından ya da endeks vadeli kontratlarından uzaklaştırması durumunun hangi regülatör tarafından kontrol edileceği, yaptırımlarının ne olacağı, hangi tarafı ilgilendireceği, fişin kimin tarafından ne zaman çekileceği önümüzdeki dönemin ve sermaye piyasalarının en önemli sorunlarından biri olacaktır. Nitekim, robot algoritmaların Foreks piyasalarda işlem yapması da benzer nedenler ile SPK tarafından 757 sayılı Genel Mektupta bir düzenleme ile (bugün için) engellenmiştir (Dirican, Şalom 2017, ET:2017).

Son olarak, bu çalışmada ARDL sınır testi analizi kapsamında Bitcoin bağımlı değişken olarak alınıp 7 adet bağımsız değişken borsa endeksi ile karşılaştıııldığında Çin ve ABD Borsaları ile aralarında yatırım kararı anlamında bir eşbütünleşme ilişkisi tespit edilmiştir. Bu doğrultuda dünyanın ilk iki büyük ekonomisinde yatırımcıların Bitcoin'in fiyatındaki hareketleri kendi yatırım kararlarında dikkate aldığı söylenebilecektir. Visa'nın Cambridge Üniversitesi Judge Business School ile küresel kripto para kıyaslama çalışma raporunda da ilginç bir rastlantı olarak Kuzey Amerika ve Uzakdoğu'da, Asya Pasifik'te yerleşik kripto para firmalarında diğer bölgelere göre daha çok personel çalışmaktadır (Hileman ve Rauchs, 2017:25). Bu durumu pazarlar olgunlaştıkça Bitcoin'in borsalar ile yatırımcı kararlarını yakınlaştırdığı şeklinde okumak mümkündür. Öte yandan çalışmadaki diğer 3 borsa endeksinde ilişkinin görülmemesi buradaki yatırımcıların konuya duyarsızlığı olarak değil hisse senedi yatırım kararlarında Bitcoin'deki gelişmelerden bağımsız düşündükleri ve davrandıkları şeklinde yorumlanmalıdır. ABD borsalarındaki yatırımcıların Bitcoin'i dikkate almasındaki en önemli etken olarak 2017 sonu itibarı ile Chicago Emtia Borsası'nın (CME) Bitcoin vadeli işlem piyasasını ve vadeli kontrat işlemlerini devreye alacağı duyurusunun bulunduğu iddia edilebilir (cmegroup.com, 2017, ET:2017). Bu doğrultuda Bitcoin diğer ABD borsalarından önce CME'de işlem görmeye başlayacağı için bir emtia olarak mı öncelikle kabul görmektedir sorusunun cevaplanmasına da ışık tutacaktır. BiST100 endeksi ile bir ilişki çıkmaması ise daha çok Türkiye'deki yatırımcıların konuyu geriden takip etmesi ve mevzuattaki boşluklar ile yabancı piyasaların takibinde yabancı lisan bilme gereksinimi olarak iddia edilebilir. İşlem hacmi, pazar değeri boyutları ile çalışmanın ele alınması durumunda zaman serilerinin gelişeceğinden ve gözlem sayısının artacağından hareketle ileride farklı bulguların oluşması mümkündür. BiST Banka Endeksi XBANK, BIST Teknoloji Endeksi XUTEK ve dünyadaki teknoloji ve bankacılık endeksleri ile birlikte analiz edilmesi fintek gelişimi açısından da önemli bulgu ve sonuçlar ortaya çıkaracaktır.

\section{SONUÇ VE ÖNERILER}

Fintek kavramı ışığında finans ve teknolojinin yakınsaması dahilinde yukarıda incelenmesi gerekli görülen yatırım, para, ödeme sistemleri, e-ticaret başıklarının her biri ayrı bir makale, bildiri, tez konusu veya kitap olabilecek derinlik içermektedir. Yatırım boyutunun haricinde bu başlıklardan sadece birini kısaca örnek olarak irdelersek, örneğin b4 şıkkı, merkez bankalarının işlevleri arasında banknot basımı, parasının değeri ile satın alım gücünü koruma amacı, kaydi para yaratımında zorunlu karşılık uygulaması gibi başlıklar bulunmaktadır (Yalta, 2011:9). Eğer kripto paraların ihracı ve kontrolü zaman içerisinde merkez bankalarını lehine gelişmez ise, yani kendilerinin çıkarması, mevcut olanların bilançolarına dahil olması veya regülasyon ile kontrolü altına girmesi gibi, merkez bankacılığında ve bundan hareketle bankacılık kavramlarında yıkıcı bir dönüşüm olacaktır.

Literatürde ve profesyonel çalışmalarda Bitcoin ve hisse senetleri arasındaki ilişkiyi araştıran neredeyse yok denecek seviyede limitli görüldüğünden, volatilite ve getiri boyutundan dikkat çeken Bitcoin hisse senedi gibi bir yatırım enstrümanı olarak analiz edilmek istenmiştir. ARDL sınır testi yapılarak Bitcoin ve önde gelen bazı borsa endeksleri ile uzun vadeli eşbütünleşme ilişkisinin görülmesi nedeni ile Bitcoin ve diğer kripto paraların para, e-ticaret, ödeme sistemleri boyutlarından da incelenmesi anlamlı bulunmuştur. Bu meyanda Bitcoin ve kripto paraların emisyon, M1 gibi merkez bankalarının para arzı tanımları ve altının onsu ile ilişkisinin bir sonraki çalışmada analiz edilmesine karar verilmiştir. Çalışmada bulunan $A B D$ ve Çin borsalarının endeksleri ile Bitcoin arasındaki eşbütünleşme ilişkisi ışı̆̆ında yatırımcı kararlarında ve birbirleri üzerinde etkileri olduğu sonucu çıkarılabilecektir. Bu bulgudan hareketle, Bitcoin'i vadeli kontratlarda işlem görmesi için kabul eden Chicago Borsası gibi, Borsa İstanbul'da ve TCMB Para Piyasasında işlem görmesi yönünde çalışmalar yapılması, kripto ve elektronik paralara yönelik endeks oluşturulması ve SPK, TCMB, BDDK'nın regülasyonları çerçevesinde istatistiklerinin tutulması önerilmektedir. Öte yandan sigortacılık ve bireysel emeklilik boyutundan da konunun süreç içerisindeki gelişimine göre değerlendirilmesi önem arz edecektir. Blok zincirlerinin finansal hizmetler dışında örneğin dış ticaret işlemlerinde yaratacağı etkilere de ayrıca bakııması fayda sağlayacaktır.

\section{KAYNAKÇA}

Atik, M., Köse, Y., Yılmaz, B., \& Sağlam, F. (2015). Kripto Para: Bitcoin ve Döviz Kurları Üzerine Etkileri. Bartın Üniversitesi iliBF Dergisi, 6(11), ss.247-262, http://dergipark.gov.tr/download/article-file/40159, (Erişim Tarihi: 03.11.2017)

Baek, C., \& Elbeck, M. (2014). Bitcoins as an Investment or Speculative Vehicle? A First Look. Applied Economics Letters, 22(1), pp.30-34, http://www.tandfonline.com/doi/full/10.1080/13504851.2014.916379?scroll=top\&needAccess=true, (Erişim Tarihi: 03.11.2017)

Bankaclık Düzenleme ve Denetleme Kurumu, Resmî Gazete (27 Haziran 2013 Perşembe) Sayı: 28690. Ödeme Ve Menkul Kiymet Mutabakat Sistemleri, Ödeme Hizmetleri Ve Elektronik Para Kuruluşlari Hakkinda Kanun. Kanun No.6493, Kabul Tarihi: 20/6/2013, 
https://www.bddk.org.tr/WebSitesi/turkce/Mevzuat/Odeme_Hizmetleri_Kanunu/122586493_sayili_kanun_ptt_352017.pdf, (Erişim Tarihi: 05.11.2017)

Bloomberght.com, (2017). Japonya 11 Bitcoin Borsasına Faaliyet İzni Verdi. Bloomberght.com Haber Sitesi Web Sayfası, 29 Eylül 2017 Cuma, 14:59, Güncelleme: 29 Eylül 2017 Cuma, 15:00, http://www.bloomberght.com/haberler/haber/2053434-japonya-11-bitcoinborsasina-faaliyet-izni-verdi, (Erişim Tarihi: 09.11.2017)

Brown, R. L., Durbin, J., \& Evans, J. M. (1975). Techniques for Testing the Constancy of Regression Relationships over Time. Journal of the Royal Statistical Society, pp.149-192, http://pds9.egloos.com/pds/200807/01/78/CUSUM_TEST.pdf, (Erişim Tarihi: 03.11.2017)

Borsanedir.tv (2017). BiST100 Endeksi nedir?. Borsa İstanbul A.Ş. Web Sitesi, http://www.borsanedir.tv/piyasalar/pay-piyasasi/paypiyasasi-endeksleri/bist-100-endeksi/, (Erişim Tarihi: 05.11.2017)

Bouoiyour, J., Selmi, R., \& Tiwari, A. K. (2015). Is Bitcoin Business Income or Speculative Foolery? New Ideas through an Improved Frequency Domain Analysis. Annals of Financial Economics, 10(01), pp.1-23, https://www.researchgate.net/profile/Refk Selmi/publication/ 275408281 Is Bitcoin business income or speculative foolery New ideas through an improved frequency domain analysis/links/55 3ddc060cf2c415bb0f7c6a.pdf, (Erişim Tarihi: 03.11.2017)

Bovaird, C. (2017). Follow the Leader: Analyzing Cryptocurrency Price Correlations. coindesk.com Web Bilgi Sitesi, Mar 25, 2017 at 14:30 UTC, https://www.coindesk.com/follow-leader-analyzing-bitcoin-cryptocurrency-price-correlations/, (Erişim Tarihi: 09.11.2017)

Chester, J. (2017). A New Way To Raise Money: The Initial Coin Offering. Forbes.com Haber Web Sitesi, Jun 12, $2017 @ 07: 32$ AM, https://www.forbes.com/sites/jonathanchester/2017/06/12/a-new-way-to-raise-money-the-initial-coin-offering/\#4e44a8375fb5, (Erişim Tarihi: 09.11.2017)

Cheung, A., Roca, E., \& Su, J. J. (2015). Crypto-Currency Bubbles: An Application of the Phillips-Shi-Yu (2013) Methodology on Mt. Gox Bitcoin Prices. Applied Economics, 47(23), pp.2348-2358, https://espace.curtin.edu.au/bitstream/handle/20.500.11937/45230/ 227311 227311.pdf?sequence $=2$, (Erişim Tarihi: 03.11.2017)

Cmegroup.com, (2017). CME Group Announces Launch of Bitcoin Futures. Chicago Mercandile Exchange cmegroup.com Web Sitesi, News Release, Tue Oct 31 2017, http://www.cmegroup.com/media-room/press-releases/2017/10/31/cme group announceslaunchofbitcoin futures.html, (Erişim Tarihi: 09.11.2017)

Coinmarketcap.com, https://coinmarketcap.com/currencies/bitcoin/\#markets (Erişim Tarihi: 07.11.2017)

Dirican, C. (2000). Internet'in ve Internet Bankacılığı’nın Finansal Hizmet Sektöründeki Yeri ve Etkileri. T.C. Marmara Üniversitesi, Bankacılık ve Sigortacılık Enstitüsü, Sermaye Piyasası ve Borsa Anabilim Dalı, Yüksek Lisans Bitirme Tezi, ss.123-135

Dirican, C. (2017). Sosyal Medyanın Davranışsal Finansta Rolü. Şalom Gazetesi Ekonomi Web Sayfası, 22 Mart 2017, http://www.salom.com.tr/newsdetails.asp?id=102498, (Erişim Tarihi: 09.11.2017)

Dyhrberg, A. H. (2015). Hedging Capabilities of Bitcoin. Is it the Virtual Gold?. Finance Research Letters, 16, pp.139-144. http://irserver.ucd.ie/bitstream/handle/10197/7169/WP15 21.pdf?sequence=1, (Erişim Tarihi: 03.11.2017)

Engle, R. F., \& Granger, C. W. (1987). Co-Integration and Error Correction: Representation, Estimation, and Testing. Econometrica: Journal of the Econometric Society, pp.251-276, http://www.jstor.org/stable/1913236?seq=1\#page_scan_tab_contents, (Erişim Tarihi: 03.11.2017)

Ergen, M. (2017). Geçmişten Günümüze ICO ve Bitcoin. fintechistanbul.org Web Bilgi Sitesi, Yazı Orijinal Yayın: ICT Medya Dergisi, Kasım 2017, http://fintechistanbul.org/2017/11/09/gecmisten-gunumuze-ico-ve-bitcoin/, (Erişim Tarihi: 09.11.2017)

Eswara, M. (2017). Cryptocurrency Gyration and Bitcoin Volatility. International Journal of Business and Administration Research Review, 3(18), pp.187-195, http://www.ijbarr.com/downloads/1908201732.pdf, (Erişim Tarihi: 03.11.2017)

Eviews.com (2017), http://www.eviews.com, (Erişim Tarihi: 05.11.2017)

Fintechistanbul.com, (2016). Akıllı Sözleşmeler Birliği Kuruldu. Fintechistanbul.org Web Sitesi, Blockchain Haber Sayfası, 29 Temmuz 2016, http://fintechistanbul.org/2016/07/29/akilli-sozlesmeler-birligi-kuruldu/, (Erişim Tarihi: 09.11.2017)

Gcmforex.com (2017). GMC Foreks Menkul Kıymetler A.Ş. Web Sitesi, Borsa Endeksleri Sayfası, https://www.gcmforex.com/yatirimaraclari/borsa-endeksleri/, (Erişim Tarihi: 05.11.2017)

Glaser, F., Zimmermann, K., Haferkorn, M., Weber, M. C., \& Siering, M. (2014). Bitcoin-asset or Currency? Revealing Users' Hidden Intentions. Twenty Second European Conference on Information Systems, Tel Aviv, pp.1-14, https://pdfs.semanticscholar.org/3c7d/998b88bf48c88cf693625d2852706e7cb8e4.pdf, (Erişim Tarihi: 03.11.2017)

Hileman, G. \& Rauchs, M. (2017). Global Cryptocurrency Benchmarking Study. The Judge Business School at Cambridge University \& VISA, p.25, https://www.jbs.cam.ac.uk/fileadmin/user upload/research/centres/alternative-finance/downloads/2017-global-cryptocurrencybenchmarking-study.pdf, (Erişim Tarihi: 09.11.2017)

Investing.com, https://tr.investing.com/ Erişim Tarihi: 05.11.2017)

İskenderoğlu, L. (1988). Uluslararası Para Sisteminin Sorunları ve İyileştirme Çalışmaları. Türkiye Cumhuriyet Merkez Bankası, Araştırma Planlama Eğitim Genel Müdürlüğü, Tartışma Tebliği No.8807, Haziran 1988, ss.1-31, http://www.tcmb.gov.tr/wps/wcm/connect/6a545fe4- 
c3f7-4362-bfeb-4b29417b9dc4/8807tur.pdf?MOD=AJPERES\&CACHEID=6a545fe4-c3f7-4362-bfeb-4b29417b9dc4, $\quad$ (Erişim Tarihi: 05.11.2017)

Johansen, S. (1988). Statistical Analysis of Cointegration Vectors. Journal of Economic Dynamics and Control, 12(2-3), pp.231-254, https://tr.scribd.com/doc/76105072/Johansen-S-1988-Statistical-Analysis-of-Cointegration-Vectors, (Erişim Tarihi: 03.11.2017)

Johansen, S., \& Juselius, K. (1990). Maximum Likelihood Estimation and Inference on Cointegration - With Applications to the Demand for Money. Oxford Bulletin of Economics and Statistics, 52(2), pp.169-210, http://digidownload.libero.it/rocco.mosconi/ JohansenJuselius1990.pdf, (Erişim Tarihi: 03.11.2017)

Kancs, D’A., Ciaian, P \& Rajcaniova, M. (2014). The Economics of BitCoin Price Formation. pp.1-22, https://arxiv.org/ftp/arxiv/papers 1405/1405.4498.pdf, (Erişim Tarihi: 09.11.2017)

Kancs, D'A., Ciaian, P \& Rajcaniova, M. (2015). The Digital Agenda of Virtual Currencies Can BitCoin Become a Global Currency?. European Commission Joint Research Centre Institute for Prospective Technological Studies, JRC Technical Report, pp.1-46 http://publications.jrc.ec.europa.eu/repository/bitstream/JRC97043/the\%20digital\%20agenda\%20of\%20virtual\%20currencies final.pdf (Erişim Tarihi: 09.11.2017)

Koçoğlu, Ş., Çevik, Y. E., \& Tanrı̈̈ven, C. (2016). Bitcoin Piyasalarının Etkinliği, Likiditesi ve Oynaklığı. İ̧sletme Araştırmaları Dergisi, 8(2), ss.77-97, http://isarder.org/2016/vol.8 issue.2 article05 full text.pdf, (Erişim Tarihi: 03.11.2017)

Kointurk.net, (2017). Türkiye Cumhuriyet Merkez Bankası'ndan Bitcoin Açıklaması. Kointurk.net Web Sitesi, Bitcoin Haberleri, https://koinbulteni.com Kaynak Haberi, http://www.kointurk.net/2017/11/02/turkiye-cumhuriyet-merkez-bankasindan-bitcoinaciklamasi/, (Erişim Tarihi: 09.11.2017)

Kristoufek, L. (2015). What Are the Main Drivers of the Bitcoin Price? Evidence from Wavelet Coherence Analysis. PloS ONE, 10(4), pp.1-15, http://journals.plos.org/plosone/article/file?id=10.1371/journal.pone.0123923\&type=printable, (Erişim Tarihi: 03.11.2017)

Marian, O. (2016). Kripto Para Birimi Üstün Vergi Cenneti Mi?. Istanbul Üniversitesi Hukuk Fakültesi Mecmuası, 919, s.923, Çev./ Translated by: Sedef Pelin Gürlek Keleş, http://asosindex.com/cache/articles/kripto-para-birimi-ustun-vergi-cenneti-mi-f413344.pdf, (Erişim Tarihi: 05.11.2017)

Narayan, P. K., \& Smyth, R. (2006). What Determines Migration Flows from Low-Income to High-Income Countries? An Empirical Investigation of Fiji-Us Migration 1972-2001. Contemporary Economic Policy, 24(2), pp.332-342, https://www.researchgate.net/profile/Russell_Smyth/publication/46539589_What_Determines_Migration_Flows_from_LowIncome to High-Income Countries An Empirical Investigation of Fiji-US Migration 1972-

2001/links/59d69546458515db19c4feaf/What-Determines-Migration-Flows-from-Low-Income-to-High-Income-Countries-An-EmpiricalInvestigation-of-Fiji-US-Migration-1972-2001.pdf, (Erişim Tarihi: 03.11.2017)

Oktay, E.D. (2017). Çin BT Bakanlığı Blockchain Araştırma Laboratuvarı Kuruyor. www.koinbulteni.com Web Sitesi Haber Sayfası, 21 Eylül 2017, https://koinbulteni.com/cin-bt-bakanligi-blockchain-arastirma-laboratuvari-kuruyor-2744.html, (Erişim Tarihi: 05.11.2017)

Ödeme ve Elektronik Para Derneği, (2017). Fintek Sözlüğü. ODED Web Sayfası, https://oded.com.tr/fintek-sozlugu/, (Erişim Tarihi: 05.11.2017)

Pesaran, M. H., \& Pesaran, B. (1997). Working with Microfit 4.0: Interactive Econometric Analysis. Oxford University Press.

Pesaran, M. H., \& Shin, Y. (1998). An Autoregressive Distributed-Lag Modelling Approach to Cointegration Analysis. Econometric Society Monographs, 31, pp.371-413, https://pdfs.semanticscholar.org/743d/c1e8cf7eea4a2ac9bc58907f2ce08a1f5d90.pdf, (Erişim Tarihi: 03.11.2017)

Pesaran, M. H., Shin, Y., \& Smith, R. J. (2001). Bounds Testing Approaches to the Analysis of Level Relationships. Journal of Applied Econometrics, JohnWiley \& Sons, Ltd., 16(3), pp.289-326, https://ideas.repec.org/a/jae/japmet/v16y2001i3p289-326.html, (Erişim Tarihi: 03.11.2017)

PWC, (2016). Making Sense Of Bitcoin, Cryptocurrency, and Blockchain. Price Waterhousecoopers Consultancy US Web Sitesi, Financial Services, Fintek Sayfaları, February 2016, https://www.pwc.com/us/en/financial-services/fintech/bitcoin-blockchain-cryptocurrency.html, (Erişim Tarihi: 09.11.2017)

Rmegold.com, (2017). Gold and Cryptocurrency Forming a New Relationship?. RME Gold Web Sitesi, http://www.rmegold.com/blog/goldcryptocurrency-new-relationship/, (Erişim Tarihi: 09.11.2017)

Shaimardanov, D. (2017). Goldman Sachs Plans to Add Bitcoin to its Stock Exchange. October 11, 2017 , https://freedman.club Web Sitesi, (Erişim Tarihi: 09.11.2017)

Teknolojivefinans.com, (2017). Bitcoin Nedir ve Nasıl Çalışır?. Teknoloji ve Finans Bilgi Web Sitesi, https://teknolojivefinans.com/bitcoinnedir-ve-nas\%C4\%B1I-\%C3\%A7al\%C4\%B1\%C5\%9F\%C4\%B1r-1-dc573eeac2ef, (Erişim Tarihi: 09.11.2017)

Tr.sputniknews.com (2014). Bitcoin Borsası Varlı̆ı̆na Son Verdi. Rusya'nın Sesi Radyosu Haber Web Sitesi, 26 Şubat 2014, 15:21 https://tr.sputniknews.com/turkish.ruvr.ru/2014_02_26/Bitcoin-borsasi/, (Erişim Tarihi: 05.11.2017)

Uzmancoin.com, (2017). IMF Başkanı: Dijital Para Birimlerini Yasaklamak Akıllıca Olmayabilir. Uzmancoin.com Web Sitesi, http://uzmancoin.com/imf-bitcoin/, (Erişim Tarihi: 09.11.2017) 
Uzmancoin.com (2017). Çin'in Ardından Güney Kore De ICO’ları Yasakladı. Uzmancoin.com Web Sitesi, http://uzmancoin.com/guney-koreico/, (Erişim Tarihi: 09.11.2017)

Üzer, B. (2017). Sanal Para Birimleri. Uzmanlık Yeterlik Tezi, Türkiye Cumhuriyet Merkez Bankası Ödeme Sistemleri Genel Müdürlüğü, Ankara, Eylül 2017, ss.9-16, http://www.tcmb.gov.tr/wps/wcm/connect/5e8fd9ad-f228-458d-95bf-740626e8dadc/ Sanal+Para+Birimleri .pdf?MOD=AJPERES\&CACHEID=ROOTWORKSPACE-5e8fd9ad-f228-458d-95bf-740626e8dadc-IZ95q94, (Erişim Tarihi: 09.11.2017)

Visualcapitalist.com (2017), http://www.visualcapitalist.com/20-largest-stock-exchanges-world/, (Erişim tarihi: 07.11.2017)

Yalta, Y. (2011). Paranın Tanımı ve İşlevleri. Açıkders Notları, Acikders.org.tr Açık Kaynak Bilgi Sitesi, Ekim 2011, s.11, http://www.acikders.org.tr/mod/resource/view.php?id=1298 ve http://www.acikders.org.tr/course/view.php?id=70 , (Erişim Tarihi: 05.11.2017)

Yermack, D. (2013). Is Bitcoin a Real Currency? An Economic Appraisal. NBER Working Paper No. 19747, National Bureau of Economic Research, December 2013, Revised April 2014, pp.1-22, http://www.nber.org/papers/w19747.pdf, (Erişim Tarihi: 03.11.2017)

Zengin, B. \& Güngördü, A. (2013). Elektronik Ödeme Sistemlerinin Olası Etkileri Üzerine Bir İnceleme. Gazi Üniversitesi iktisadi ve Idari Bilimler Fakültesi Dergisi, Cilt 15, Sayı 3, (2013), ss.129-150, http://www.iibfdergisi.gazi.edu.tr/index.php/iibfdergisi/article/view/645/531, (Erişim Tarihi: 05.11.2017) 